\title{
INQUÉRITO POLICIAL: UM INSTRUMENTO EFICIENTE E INDISPENSÁVEL À INVESTIGAÇÃo
}

\author{
Franco Perazzoni \\ Wellington Clay Porcino Silva
}

Departamento de Polícia Federal<smiles>C=[W]#[W]</smiles>

\begin{abstract}
RESUMO
O recrudescimento da violência, nestes últimos anos, conduziu-nos a um cenário de intensa desconfiança no Sistema de Justiça Criminal', sobretudo na Segurança Pública. Para alguns, a verdadeira panaceia universal dos graves problemas de Segurança Pública brasileiros seria tão somente a adopção de modelos estrangeiros de estrutura policial e, por conseguinte, de investigação criminal, como se o avanço da criminalidade não fosse causado pelas inúmeras mudanças sociais ocorridas ao longo das últimas décadas, mas, sim, pela opção histórica que o Brasil fez a respeito de seu modelo de investigação criminal. Ao longo deste estudo, procurar-se-á demonstrar que os resultados investigativos obtidos por forças policias dependem muito mais do tipo de crime investigado e da sociedade na qual tal corporação se encontra inserida do que do modelo de investigação adotado. Verificar-se-á, também, que no Brasil, a despeito das inúmeras críticas, diversas unidades de polícia judiciária têm obtido resultados expressivos, em patamares até superiores ao de polícias estrangeiras, consideradas de referência. Ademais, veremos que, para além do aspecto qualitativo, o inquérito policial brasileiro, devido à natureza imparcial da autoridade que o preside, isto é, o delegado de polícia, é aquele que melhor se adequa a um processo penal verdadeiramente garantista, sem descuidar da necessária proteção à sociedade.
\end{abstract}

Palavras-Chave: Sistemas de Investigação Criminal. Inquérito Policial. Taxa de Elucidação de Crimes. Eficiência. Garantismo.

\section{Sistemas de InVestigaÇÃo Criminal}

A investigação criminal pode se afigurar como sendo um procedimento judicial ou administrativo, caso o órgão encarregado pela investigação pertença ou não ao Poder Judiciário, respectivamente.

1 Aqui englobando os seguintes subsistemas: I) Segurança Pública (composto por todo o aparato preventivo do Estado, que visa evitar a ocorrência de crimes, dentre eles, destacadamente, as polícias administrativas e preventivas criminais); II) Justiça Criminal strictu sensu (composto pelos atores que atuam após a suposta prática delituosa, a saber: Polícia Judiciária, Judiciário, Parquet e Defensoria/ Advocacia); e III) Sistema Penitenciário. 
Na primeira hipótese, encontramos os sistemas de juizados de instrução, conduzidos pela Autoridade Judiciária, cujos atos, naturalmente, são judiciais.

$\mathrm{Na}$ segunda, temos o inquérito policial, cujas investigações são titularizadas pela Autoridade de Polícia Judiciária.

Importante ter em mente que essa classificação da instrução prévia como judicial ou administrativa, considera apenas a natureza do próprio órgão incumbido de investigar (o Estado-investigação).

Ocorre, entretanto, que se focarmos nossa atenção na finalidade da própria investigação estatal, qual seja, a de persecutio criminis extrajudictio, com vistas ao esclarecimento de fatos e circunstâncias a cerca de uma possível prática delituosa, até mesmo o inquérito policial pode e deve ser visto como um procedimento judicial (PITOMBO, 1987, pp. 21-22).

Feitas essas considerações iniciais, passaremos, a seguir, a abordar, brevemente, cada um dos modelos ou sistemas de investigação criminal vigentes no mundo moderno, a saber: a) o juizado de instrução; b) o inquérito ministerial; e c) o inquérito policial.

\subsection{Do JUIZADO DE INST RUÇÃo (JUIZ-INVESTIGADOR)}

É o modelo mais antigo, tendo dele derivado os demais sistemas hoje conhecidos.

Neste sistema, a presidência da investigação criminal é titularizada por um magistrado, denominado juiz de instrução, juiz-instrutor ou juiz-investigador. A Polícia Judiciária se afigura, neste caso, como mero órgão auxiliar, diretamente subordinada ao magistrado no plano funcional. Dentre as atribuições do juiz instrutor encontram-se, por exemplo, proceder ao formal interrogatório do suspeito, determinar medidas cautelares pessoais ou reais, colher todos os elementos de convicção necessários ao esclarecimento do fato noticiado e requisitar perícias.

A iniciativa e os poderes instrutórios encontram-se inteiramente concentrados na figura do juiz instrutor. A participação da defesa e do órgão acusador limita-se a simples solicitação da realização de diligências, as quais poderão ser deferidas ou não, a seu talante (LOPES JR, 2003, p. 72). 
Foi o sistema adotado pelo Brasil até 1871 e cogitou-se, quando da edição do Código de Processo Penal vigente, pela sua readoção, o que foi descartado, justamente pelas suas desvantagens, conforme bem exposto na respectiva exposição de motivos.

Dentre as principais desvantagens apontadas para este sistema, afigura-se destacadamente o excesso de poderes conferidos a uma única pessoa ${ }^{2}$.

Adotam este sistema, atualmente, a França e a Espanha, dentre outros ${ }^{3}$.

\subsection{Do Promotor-InVESTIgAdor (SISTEMA CONTINENTAL EUROPEU)}

É o sistema adotado, hoje, na maioria dos países da Europa Continental, América Latina e nos EUA ${ }^{4}$.

No sistema do promotor-investigador, o órgão acusador é que preside as investigações, cabendo a Polícia Judiciária, como no sistema do juizado de instrução, apenas auxiliá-lo.

Tomando-se como exemplo a Itália (país que até 1988 adotava o sistema de juizado de instrução, passando a adotar, desde então o promotor-investigador), podemos ter uma razoável panorâmica desse modelo de investigação prévia.

2 Isto porque, além de presidir os autos investigativos em si, o juiz-instrutor é quem autoriza as medidas cautelares necessárias à apuração do fato supostamente tido como delituoso. Tal característica, a nosso ver, desvirtuaria o sistema acusatório esposado na $\mathrm{CF} / 88$, pois, obviamente, não pode o mesmo ator que preside e executa a investigação, avaliar a legalidade dos atos restritivos de direitos e garantias fundamentais.

3 Na prática, entretanto, o juiz, nesse sistema, acaba por delegar suas funções investigatórias a outros funcionários, conforme se infere do seguinte trecho que nos mostra o que ocorre, hoje, no Uruguai: “(...) la práctica judicial indica, -por lo menos en nuestra capital - que el juez realiza una delegación de funciones en sus funcionarios administrativos, y 'no procede directamente a la investigación de los hechos', como lo impone la normativa vigente (arts. 115 y $135 \mathrm{CPP}$ ), en razón de la acumulación de tareas y del aumento significativo de causas a su estudio" (UBIRIRIA, 2015).

4 Segundo Bruno Calabrich (2007, p. 79-80), o modelo adotado pelos norte-americanos apresenta, dentre todos os vigentes, o que se desataca com a maior preponderância do Ministério Público na investigação preliminar, pois não há qualquer "controle judicial valorativo no correr da fase investigativa nem no caso de seu arquivamento (...) Seu poder discricionário permite (...) e mesmo negociar com o investigado a troca de uma admissão de culpa por uma pena reduzida ou por uma desqualificação do delito para tipos com sanções menos severas ('plea bargaining')”. 
As investigações ("indagini preliminari”) têm início a partir da notícia-crime, cabendo ao Ministério Público a apuração dos fatos.

As atribuições do promotor-investigador encontram-se previstas nos arts. 358 a 378 da Lei de Processo Penal Italiana, dentre elas, destacadamente: a) receber a notícia-crime e decidir sobre a instauração de procedimento investigativo; b) efetuar todas as diligências investigativas necessárias ao exercício da ação penal; c) interrogar o investigado e ouvir testemunhas; d) nomear peritos para realização de exames; e) ordenar, em caso de urgência, acareações inspeções, seqüestros, buscas pessoais e locais, além de interceptações; e f) oferecer acusação formal.

Por seu turno, o caráter de mero auxiliar atribuído à Polícia Judiciária, fica bastante evidenciado das atribuições que lhe são previstas nos arts. 347 a 357 do mesmo diploma legal, senão vejamos: a) receber a notícia-crime e transmiti-la ao Ministério Público; b) assegurar as fontes de prova, conservando o estado de lugares e coisas úteis a reconstrução dos fatos e individualização do suspeito; c) tomar declarações espontâneas do suspeito, que não poderão ser utilizadas em juízo (fase de "dibattimento"), salvo exceções previstas em lei; d) realizar busca pessoal ou local, em caso de flagrante delito ou fuga, encaminhando os resultados ao Ministério Público em quarenta e oito horas, para convalidação; e)apreender correspondências e documentos e encaminhá-los intactos ao Ministério Público; f) elaborar relatório das atividades desenvolvidas e colocá-lo à disposição do Ministério Público.

O Código de Processo Penal Italiano (art. 373) prevê que todos os atos que integram as investigações serão registrados na forma escrita, bem como que os respectivos autos serão conservados junto ao cartório do Ministério Público.

Também é de suma importância ressaltar-se que os atos que integram as andagini preliminari não são produzidos sob o crivo do contraditório (a exemplo do que ocorre no juizado de instrução e no inquérito policial) e, portanto, via de regra, não são aproveitáveis na fase judicial.

Outro fato, desconhecido por muitos, é de que nos países que adotaram a investigação ministerial, nestes últimos anos, surgiram duas novas situações que nos remetem à reflexão.

A primeira delas é que, mesmo nos ricos e poucos extensos países europeus, o Ministério Público não dispõe de membros suficientes e efi- 
cazmente capacitados para instaurar e acompanhar todas as investigações criminais em curso.

A conseqüência é óbvia: embora formalmente esse modelo defina o Ministério Público como responsável pela investigação criminal, na prática, a investigação é conduzida pelas polícias, que, entretanto, não são dotadas dos poderes, prerrogativas e da independência necessária ao fiel cumprimento dessa tarefa.

Este fenômeno, denominado em Portugal de "policialização da investigação criminal", já há alguns anos gera diversas discussões no meio jurídico lusitano, notadamente no que se refere à validade, sob o prisma constitucional, de investigações que não tenham sido efetivamente conduzidas pelo Ministério Público, órgão incumbido constitucionalmente de tal mister. ${ }^{5}$

A outra situação, hoje corrente, é de que a titularidade da investigação pelo Ministério Público nos países que adotam o referido sistema, não guarda efetiva consonância com os ditames de um sistema verdadeiramente acusatório, muito pelo contrário, senão vejamos.

Acusatório não é apenas o sistema processual que concebe o juiz como um sujeito distinto das partes, mas, principalmente aquele que garante, efetivamente, uma contenda entre iguais, restando, sobretudo, a figura do juiz como um moderador imparcial (FERRAJOLI, 1995, p. 564).

Nesta esteira de raciocínio, irretocáveis os ensinamentos de Aury Lopes Jr. (2001, p. 97), alertando-nos dos graves perigos em que incorre o órgão ministerial ao aventurar-se como investigador:

Na prática, o promotor atua de forma parcial e não vê mais que uma direção. Ao se transformar a investigação preliminar numa via de mão única, está-se acentuando a desigualdade das futuras partes com graves prejuizos para o sujeito passivo. É converte-la em uma simples e unilateral preparação para a acusação, uma atividade minimista e reprovável, com inequivocos prejuizos para a defesa.

5 É interessante saber que, em Portugal, face ao referido fenômeno, o que se verifica é uma forte tendência pela redução do papel desempenhado efetivamente pelo Parquet na investigação preliminar, inclusive com a delegação para a presidência do inquérito para as Polícias Criminais. Neste sentido é a Lei da Organização da Investigação Criminal (Lei no 21/2000, de 10-8), bem como a reforma de 1998 no art. $270^{\circ}$ do Código de Processo Penal Português (COSTA, 2003). 
Daí porque, aliás, é que surgiu na Itália a Lei no 397/2000, que alterou substancialmente diversos artigos do Código de Processo Penal Italiano, buscando, com isso, viabilizar, uma maior paridade de armas entre as partes na persecução penal, prevendo ao defensor a possibilidade de realizar a chamada investigação defensiva, ou seja, realizar atos investigativos cujo valor probatório seja equiparado juridicamente àqueles produzidos pela acusação.

Obviamente isso não é simples e os resultados práticos são bastante questionáveis.

Afinal, diversamente do titular da investigação que dispõe da coercitividade do poder estatal para a obtenção da prova, a defesa continua a figurar numa posição bastante vulnerável ${ }^{6}$.

\subsection{Do Inquérito Policial (Sistema Inglês)}

É, em linhas gerais, o principal sistema investigativo adotado no Bra$\mathrm{sil}^{7}$ e tem suas origens no modelo Inglês de investigação preliminar.

O modelo inglês ("inquérito policial") distingue-se nitidamente do sistema continental ("inquérito ministerial") uma vez que as investigações neste modelo são conduzidas pela Polícia, a qual age em virtude de um poder que lhe é próprio.

6 Por outro lado, se a investigação preliminar for dirigida pela Polícia Judiciária, a investigação defensiva, a princípio, não seria imprescindível, em razão do dever de imparcialidade deste órgão (MACHADO, 2010, p. 46).

7 Dizemos "principal modelo", porque, em verdade, no Brasil, coexistem, ainda, os três modelos assinalados. Afinal, mesmo com a extinção do Inquérito Judicial nos crimes falimentares, a Lei Orgânica Nacional da Magistratura prevê, expressamente, em seu art. 33 que apenas magistrados poderão investigar seus pares. Da mesma forma, a autoridade policial, ao tomar conhecimento de crimes praticados por membros do Parquet, deverá remeter os autos ao órgão ministerial, a quem competirá prosseguir as investigações, nos termos do art. 41 da respectiva Lei Orgânica Nacional do Ministério Público. Temos ainda, a nosso ver equivocadamente, visto nestes últimos anos, uma ampliação das hipóteses de juizado de instrução por aqui, com as sucessivas decisões judiciais, que tem atribuído, aos tribunais superiores, a autoridade para investigar os crimes praticados por autoridades com prerrogativa de foro. Da mesma forma, para além da investigação de crimes praticados pelos próprios membros do Parquet, em que existe expressa previsão legal de que tais investigações estejam a cargo do órgão ministerial, os Procedimentos Investigativos Criminais (PICs) conduzidos diretamente pelo Ministério Público, revelam-se, hoje, flagrante tentativa de instalação, por aqui, de um sistema de acusador-investigador, supostamente nos mesmos que os países da Europa Continental, ainda que, na verdade, os controles e restrições por lá existentes, aqui, sequer sejam cogitados. 
Na Inglaterra, ainda hoje ${ }^{8}$, tanto a abertura como a conclusão e o eventual arquivamento das investigações compete única e exclusivamente à polícia. Ao "Chief Officer" (equivalente ao nosso delegado de polícia), além do arquivamento das investigações, compete, ainda, dar início à ação penal, passando a acusação ("Crown Prosecutor") a agir apenas após iniciada a ação penal.

Tem-se, portanto, que o inquérito policial é o nomem juris do modelo investigativo em que, a exemplo do adotado na Inglaterra e na Austrália, incumbe única e exclusivamente à Autoridade Policial definir a linha investigativa, praticando diretamente os atos pertinentes ao esclarecimento dos fatos tidos como delituosos, exceto os que impliquem restrição a direitos e garantias fundamentais, que exigem a prévia autorização judicial.

Feitos esses esclarecimentos que julgávamos oportunos, a seguir relacionaremos dois pontos que, cremos são de fundamentação importância à conclusão deste trabalho: I) uma abordagem, ainda que geral, do(s) sistema(s) investigativo(s) hoje existente(s) no Brasil; II) a avaliação quanto a sua eficiência, quando comprando com os demais sistemas existentes sob dois aspectos distintos, mas que cremos fundamentais: a) proteção de direitos individuais e garantias fundamentais do investigado; e b) elucidação de crimes.

\section{Algumas Observaçóes Preliminares sobre o(s) SISTEMAS(S) INVESTIGATIVO-CRIMINAL(IS) NO BRASIL}

Por óbvio, ao tratarmos dos sistemas investigativos, no Brasil, o primeiro modelo que nos vem à cabeça é justamente o do inquérito policial.

Ocorre, entretanto, como já referido, que há, muito, o próprio ordenamento pátrio já prevê que nos casos de delitos praticados por magistrados ou membros do Ministério Público, as investigações sejam conduzidas por

8 São inverídicas, portanto, as afirmações de que, além do Brasil, o inquérito policial existiria apenas no Uganda, Quênia e Indonésia. Em verdade, nenhum dos referidos países adota o inquérito policial. O Uganda adotou o juizado de instrução de 1950 a 1995, quando, então, sua nova Constituição passou a adotar o sistema do promotor-investigador (Constituição da República de Uganda, art. 119). O mesmo ocorre na Indonésia, onde o promotor, além de investigar diretamente, também possui poderes típicos de autoridade judiciária, como determinar prisões ou arquivar diretamente as investigações, sem controle jurisdicional (art. 14 do Código de Processo Penal da Indonésia, alíneas "c", "h" e "j"). O Quênia adota o sistema de Juizado de Instrução: a polícia apenas cumpre as determinações do respectivo magistrado, ou age por sua delegação específica em alguns casos, não dispondo, entretanto, de poderes próprios e autônomos para investigar. Por outro lado, o inquérito policial é o modelo investigativo vigente na Inglaterra, Nova Zelândia, Austrália, Irlanda, Irlanda do Norte, dentre outros. 
seus pares ${ }^{9}$. Nesses casos, a autoridade policial, ao tomar conhecimento de crimes praticados por membros do Parquet, deve remeter os autos ao órgão ministerial ou ao juízo competente, a quem competirá prosseguir as investigações, nos termos dos respectivos estatutos.

Para além disso, apesar da salutar extinção do Inquérito Falimentar, assistimos, nestes últimos anos, a uma grave ampliação das hipóteses de juizado de instrução por aqui, a partir das sucessivas decisões judiciais que atribuíram, com base nos regimentos internos dos Tribunais Superiores, exclusividade de poderes aos magistrados dessas cortes para investigar crimes praticados por autoridades com prerrogativa de foro.

Temos, ainda, os Procedimentos Investigativos Criminais (PICs) conduzidos diretamente pelo Ministério Público, também a nosso ver sem qualquer previsão legal e que se revelam, hoje, em flagrante tentativa de instalação, por aqui, de um sistema de acusador-investigador, supostamente nos mesmos que os países da Europa Continental, ainda que, na verdade, os controles e restrições por lá existentes, aqui, sequer sejam cogitados.

Em outras palavras, ao sabor de opiniões contraditórias e de circunstâncias, motivos e sentimentos os mais diversos, instalou-se, de fato, no Brasil, um modelo investigativo-criminal eclético e caótico, em que investigações policiais, judiciais e ministeriais coexistem, muito embora o grosso do trabalho e o sucesso ou não das investigações continue a recair quase que exclusivamente sobre a Polícia Judiciária ${ }^{10}$.

Cremos, entretanto, que esse momento é valioso, pois nos permite lançar várias luzes sobre o tema da investigação criminal e, compreender, de fato, o verdadeiro valor do inquérito policial, sobretudo quando comparados aos demais modelos.

9 Nesse sentido dispõe a Lei Orgânica do Ministério Público: “Art 41. (...) Parágrafo único. Quando no curso de investigação, houver indício da prática de infração penal por parte de membro do Ministério Público, a autoridade policial, civil ou militar remeterá, imediatamente, sob pena de responsabilidade, os respectivos autos ao Procurador-Geral de Justiça, a quem competirá dar prosseguimento à apuração", bem como a Lei Orgânica da Magistratura: "Art. 33 (...) Parágrafo único - Quando, no curso de investigação, houver indício da prática de crime por parte do magistrado, a autoridade policial, civil ou militar, remeterá os respectivos autos ao Tribunal ou órgão especial competente para o julgamento, a fim de que prossiga na investigação".

10 Afinal, na esmagadora maioria das vezes, as diligências, perícias, buscas, prisões, oitivas e interrogatórios, assim como todos os demais atos investigativos continuam a ser realizados pela polícia. 
Afinal, as principais críticas que se fazem ao inquérito policial seriam, justamente, a de que: a) se trata de procedimento inquisitivo e burocrático, onde não haveria contraditório e, portanto, em descompasso com o moderno processo penal, garantista e acusatório; b) resultaria em baixa taxa de solução de crimes, sobretudo os mais graves como homicídios.

Veremos, entretanto, que as críticas, são, em verdade, infundadas, conforme a seguir.

\section{Inquérito Policial $x$ Direitos e Garantias FUNDAMENTAIS}

No Brasil, o inquérito policial se rege pelo princípio da informalidade (não havendo, necessariamente, uma cadeia de atos a serem desempenhados pela autoridade que o preside, muito embora, a lei processual, estabeleça, em linhas gerais, em seu art. $6^{\circ}$, um rol mínimo e exemplificativo de diligências e ações a serem tomadas pelo delegado de polícia a partir do conhecimento da prática de uma infração penal).

A determinação legal de que seja escrito e autuado segue conforme vimos, a mesma lógica adotada para os demais modelos investigativos adotados no mundo hodierno e a crítica que muitas das vezes se faz à prática cartorária em sede de polícia judiciária decorre naturalmente da própria titularidade das investigações, pois, como vimos, por exemplo, no caso das indagini preliminari italianas, em que, sendo o Ministério Público o titular da investigação preliminar, cabendo-lhe realizar as diligências investigativas, inclusive oitivas e interrogatórios, produzir o caderno apuratório, autuá-lo, também, por óbvio lhe cabe manter o respectivo cartório (arts. 358 a 378 do CPP Italiano).

A exigência de formação jurídica do Delegado de Polícia, autoridade incumbida da persecutio criminis extra juditio, por seu turno, se afigura não apenas em estrita consonância com uma investigação garantista e imparcial, mas, sobretudo, com os modelos investigativos adotados no mundo moderno e com a tradição do direito brasileiro, marcadamente de matizes romanos.

Isto porque, nos países que adotam tradição jurídica semelhante, as investigações e os demais atos de polícia judiciária, historicamente, são dirigidas e coordenadas por magistrados (juízo de instrução) ou membros do ministério 
público (promotor-investigador), o que, aliás, restou bastante evidenciado ao longo deste singelo trabalho, notadamente das origens do próprio cargo em terras brasileiras, suas funções e do fato que, originalmente, os designados para o exercício dessas funções eram escolhidos dentre magistrados.

Vê-se, portanto, que as características gerais dos procedimentos investigativos (sigiloso, inquisitório, escrito e de cognição sumária), tanto no juizado de instrução como na investigação conduzida pelo Parquet não diferem em praticamente nada das características do inquérito policial.

Poderíamos dizer que, na verdade, o que diferencia esses diferentes sistemas é apenas a autoridade pública que detém a titularidade da investigação e o papel (de mero coadjuvante ou de efetivo titular da investigação) que desempenha a Polícia Judiciária em cada um deles.

Isso nos conduz a diversas conclusões.

A primeira é que o delegado de polícia, portanto, não pode nem deve ser visto como o simples chefe de uma unidade policial, a agir por determinação do verdadeiro titular da investigação criminal, como se afigura na esmagadora maioria das instituiçóes policiais no mundo, mas sim, como o próprio titular do Estado-investigação, exercendo, aqui, funções, que em todos os demais países, são exercidas por magistrados e membros do ministério público.

A segunda é que, por se tratar de procedimento dirigido pela autoridade policial, imparcial e desvinculada das pretensões de ambas as partes na persecução criminal, somos inclinados a concluir que, em verdade, dentre todos os modelos apresentados, o inquérito policial se afigura naquele que, dentre todos os demais, mais se aproxima de uma isenta apuração dos fatos relacionados na notícia-crime ${ }^{11}$.

11 Importante, portanto, que as autoridades policiais e demais operadores do direito, dentre eles destacadamente o integrantes da magistratura e do ministério público, compreendam que a própria razão da existência do delegado de polícia, no Brasil, escuda-se no reconhecimento de que além da investigação preliminar ser uma função tipicamente jurídica, deve, ainda, se pautar pela imparcialidade, só plenamente obtenível, por meio da existência de um Estado-investigação que não se confunda com os futuros personagens que agirão na futura persecutio criminis in juditio. E mais: ao delegado de polícia, como titular do Estado-investigação, no Estado Democrático de Direito, cabem três importantíssimas funções: a) proteger os bens jurídicos mais importantes e ameaçados pela conduta humana; b) apurar as supostas práticas delituosas que lhe chegam a conhecimento com zelo, imparcialidade e em estrita consonância com os ditames de um sistema processual de partes, portando democrático e marcadamente acusatório e; c) proteger o próprio suspeito/investigado/indiciado dos excessos e arbítrios outrora cometidos pelo próprio estado, tendo em vista a sua condição de indivíduo, titular de garantias e direitos fundamentais. 
Isto é de suma importância, pois, deixa claro que a investigação criminal realizada através do inquérito e sob o paradigma garantista esposado na $\mathrm{CF} / 88$, não pode nem deve buscar exclusivamente confirmar a tese acusatória, muito pelo contrário: deverá, primordialmente, busca verificar a plausibilidade da imputação evitando processos desnecessários.

Nesse sentido, aliás, é importante lembrar que, apesar do caráter inquisitivo do inquérito, a legislação sabiamente autoriza à defesa e ao investigado diversas possibilidades de interferir e participar ativamente no curso das investigações no sentido de produzir provas que lhe possam ser úteis à sua defesa.

Isto porque, mesmo que comprovada a prática delituosa e oferecida denúncia pelo Parquet, as provas produzidas na fase investigativa continuarão a integrar o processo, independentemente do fato de se tratarem de elementos de convicção que favoreçam à tese acusativa ou de defesa.

Em outras palavras: o inquérito policial se dirige não apenas ao Parquet, mas também ao investigado (para o exercício de sua atividade defensiva, seja nos autos do próprio inquérito, de forma deferida, ou no âmbito do posterior processo penal, de forma ordinária) e a à própria autoridade judiciária, constitucionalmente encarregada de zelar pela sua legalidade e pelo deferimento de eventuais medidas judiciais que se façam necessárias ao seu regular curso.

Sobre o assunto, transcrevemos os ensinamentos do Prof. Dr. Luiz Flávio Gomes e do colega delegado federal Fábio Scliar:

Analisando os modelos de investigação criminal de Itália, Portugal, Alemanha, França, Espanha, Bélgica, Austria, Paises Baixos, Inglaterra, Estados Unidos da América e México, sistemas em que esta etapa está nas mãos da Polícia Judiciária ou do Ministério Público ou do Juizado de Instrução, Fausi Hassan Choukr [CHOUKR, Fausi Hassan. Garantias Constitucionais na Investigação Criminal. $2^{a}$ Ed. Rio de Janeiro: Lumen Juris, 2001, p. 112] informa que neles ou não está estabelecido o contraditório ou este princípio não se aplica de forma plena, caso do ordenamento espanhol, onde o seu conteúdo é o mesmo do nosso, vale dizer, a possibilidade de requerer diligências, que podem ser negadas, e o acompanhamento do feito pelo procurador do investigado, o que comprova que nosso modelo guarda consonância com o que é praticado no mundo em temos de investigação preliminar (GOMES \& SCLIAR, 2011). 
Vê-se, portanto, que o modelo de investigação preliminar adotado pelo Brasil encontra-se em estrita consonância com o que, hoje, é praticado em todo mundo.

Vamos além: por se tratar de procedimento dirigido pela autoridade policial, imparcial e desvinculada das pretensões de ambas as partes na persecução criminal, somos inclinados a concluir que, em verdade, esse modelo investigativo se afigura naquele que, dentre todos os demais, mais se aproxima de uma isenta apuração dos fatos relacionados na notícia-crime.

Para reforçar ainda mais essa tese, cremos caber registrar que a maior parte das críticas realizadas por Ferrajoli (2010, pp. 704-745) ao subsistema penal de polícia italiano, em sua obra Garantismo Penal, não se aplicam às atividades de Polícia Judiciária desenvolvidas no Brasil, senão vejamos:

\section{CRÍTICA APRESENTADA POR FERRA- JOLI AO SISTEMA JURÍDICO ITALIANO}

Interrogatórios: Pode não ser admitida a presença de advogado no primeiro contato entre o indiciado e a polícia ou com o órgão de acusação (p. 704).

"Prisóes de Polícia": fora das hipóteses de flagrante delito, a autoridade de segurança pública e o Ministério Público podem prender pessoas "em casos excepcionais de necessidade e urgência, indicados taxativamente pela lei" (a comunicação à autoridade judiciária deve ser realizada em 48 horas sob pena de revogação). Todavia, as condições de excepcionalidade nem sempre são respeitadas (p. 730).

"Medidas de descapitalização": a Polícia Judiciária pode, independentemente de provimento judicial (art. $3^{\circ}$ da Lei 533, de 08.08.1977), realizar o "sequestro" de imóveis na flagrância de crimes concernentes às armas ou previstos nos arts. 241, 285, 286 e 306 do Código Penal (p. 732).

"Perquirição": a Polícia Judiciária pode, dentre outras hipóteses, realizar perquirição pessoal ou de local quando "subsistam particulares motivos de urgência que não consintam a emissão de tempestivo mandado de perquirição" (p. 733) ou quando tenha "notícias, ainda que por indícios, da existência de armas, munições ou materiais explosivos" (p. 734).

\section{SITUAÇÃO NO ORDENAMEN-} TO JURÍDICO BRASILEIRO

A assistência de advogado é garantida pelo art. $5^{\circ}$, LVIII, da CF/88.

Não há prisões de polícia. Não havendo flagrante delito (art. 302 do CPP), exige-se, sempre, mandado de prisão expedido pela autoridade judiciária.

Medidas de descapitalização, tais como o arresto, o sequestro e a hipoteca legal (arts. 228 e ss. do CPP), só podem ser decretadas pela autoridade judiciária.

A realização de buscas pessoais pode ser realizada nos termos do art. 244 do CPP. Buscas domiciliares exigem autorização judicial. 
Note-se, aliás, que praticamente todas as críticas realizadas por Ferrajoli à Polícia Judiciária italiana se relacionam ao exercício de atividades que, para nós, demandariam provimento jurisdicional específico.

De fato, somos da opinião que a principal vantagem do inquérito policial adotado no Brasil é definir, claramente, os papéis de cada um dos diferentes atores de acordo com sua posição e vocação institucional.

Exemplo muito forte disso é que, em 1988, ao dar cabo do antigo procedimento judicialiforme ${ }^{12}$ e deixar de prever qualquer possibilidade de expedição de mandados de busca pelas autoridades policiais ${ }^{13}$, mas reforçando, por outro lado, a opção pelo inquérito policial ${ }^{14}$, o que se operou no ordenamento pátrio foi, justamente, uma clara e inequívoca definição de papéis em estrita consonância com o Estado Democrático de Direito e um processo penal de garantias, diversamente, aliás, do que se opera nos dois outros sistemas jurídicos investigativos ainda vigentes no mundo.

Por fim, cabe-nos ressaltar um ponto pouco explorado pela doutrina nacional e que possui fortes reflexos na eficiência do inquérito quanto instrumento garantista e democrático de investigação criminal: a quantidade de controles internos e externos a que se submete.

É que as investigações realizadas, no Brasil, por intermédio do inquérito policial, "suportam sete (07) tipos de controles por membros da sociedade, em suas mais diferentes representatividades" (BARROS, 2005, p. 23), sendo o "único procedimento investigatório - entre todos os praticados nos diversos países - que permite sete maneiras de controles pelas diversas 'instituições' sociais” (BARROS, Idem, p. 26) a saber:

Como primeiro, apontamos o controle direto do juiz de Direito. Neste o inquérito será enviado ao juiz competente (arts. 10, par. $1^{\circ} \mathrm{e} 3^{\circ}$, e 23 do CPP) [...] o juiz analisa as peças do inquérito policial para evitar vicios e erronias que impeçam a busca da verdade material. O Ministério Público nutrirá duas formas de controle. A primeira,

$12 \mathrm{O}$ procedimento judicialiforme era previsto nos arts. 26 e 531 do CPP que dispunham que os processos judiciais referentes a contravenções penais seriam iniciados pelo auto de prisão em flagrante ou por portaria do delegado de polícia ou do juiz feria o sistema acusatório na medida que conferia atribuições tipicamente ministeriais (opinio delicti e denúncia) às autoridades policial e judiciária.

13 Da mesma forma, a expedição de mandados de busca domiciliar não se coadunava com o sistema acusatório na medida que conferia ao delegado de polícia poderes tipicamente jurisdicionais.

14 Ou seja: atribuindo, com exclusividade, as atividades investigativas à Polícia Judiciária. 
externa, controlando as atividades da Polícia Judiciária. A segunda, interna, mediante a verificação direta dos termos do inquérito policial, em decorrência de suas manifestações, requerendo, requisitando [...]. A Corregedoria da Polícia Civil exerce o seu controle [...]. Há, ainda, o controle exercido pelos membros da comunidade, praticando o ofendido e seus pares, vigiando a autoridade policial para evitar desmandos e tergiversaçôes. A Ordem dos Advogados do Brasil - também - exerce o seu controle externo - supralegal - das atividades da Polícia Judiciária, pois tem a missão constitucional de 'zelar pelo exercício da Justiça', conforme arts. 133 e 143 da Constituição da República. E por fim, o controle do imputado, que - nos termos do art. 14 do CPP - poderá propor a realização de diligências e oferecer testemunhas comprobatórias de sua versão (BARROS, 2005, p. 26).

\section{Inquérito Policial $x$ Taxa de Elucidação de Crimes}

Medir a eficiência investigativa de uma polícia ou, mais especificamente de um determinado modelo investigativo (inquérito, juiz de instrução ou promotor-investigador) em relação a outros, não é tarefa simples, afinal, instituições diversas lidam com recursos (humanos e materiais) e realidades sociais também distintas.

No caso da comparação entre modelos investigativos distintos, a tarefa é ainda mais complexa, pois mesmo naquelas situações em que é adotado um modelo investigativo diverso do inquérito policial (seja entre países distintos com modelos também distintos, seja no casos dentro do próprio Brasil, como nos crimes praticados por membros do MP e juízes, ou aqueles sujeitos ao procedimento investigatório junto ao STF), a tendência natural é atribuir a reponsabilidade pelo sucesso ou fracasso da investigação sempre à polícia e seus integrantes e não ao órgão que a dirige, ainda que distinto ${ }^{15}$.

15 Interessantemente, no Brasil, experimentamos, hoje, uma situação bastante desoladora, ao menos para as autoridades policiais: I) quando se trata de investigação conduzida diretamente pelo delegado de polícia, o fracasso da investigação ou supostas baixas taxas de solução de crimes são com relativa frequência atribuídas ao modelo investigativo em si, ou seja, ao inquérito policial, e ao próprio delegado que o preside, não à ausência de recursos humanos e materiais da respectiva polícia; II) quando se trata de investigação realizada sob a presidência do juiz instrutor (STF ou crimes praticados por magistrado) ou do órgão ministerial (PIC), todas ou a esmagadora maioria das diligências de campo, oitivas, perícias e demais trabalhos continuam a ser realizados, com raríssimas exceções, pela Polícia Judiciária, recaindo, novamente, sobre ela toda e qualquer responsabilidade pelo seu eventual fracasso. 
Afinal, na prática, o órgão titular determina as diligências investigativas, em alguns casos atribuindo maior ou menor liberdade ao órgão policial para a sua realização, mas é a polícia, salvo raríssimas exceções, que vai a campo, de fato, investigar a prática delituosa e coligir elementos. ${ }^{16}$

Para além disso, é preciso termos em mente que uma polícia extremamente bem aparelhada e moderna pode ser extremamente eficaz (atingimento dos resultados almejados), porém pouco eficiente (gastos e consumo de recursos para além do ideal).

Soma-se a tudo isso que mesmo crimes análogos possuem graus de dificuldade investigativa diversificada e, não raro, crimes inicialmente simples, se revelam de difícil solução, ao passo que outros, reputados mais difíceis, serão mais facilmente solucionados do que se esperava.

O ideal, portanto, é se pudéssemos dispor de indicadores de eficiência a considerar todas essas nuances, mas não temos.

De qualquer forma, um indicador frequentemente utilizado no mundo todo para avaliar o trabalho investigativo-criminal é a denominada taxa de elucidação de crimes (em inglês, clearence rate), o qual pode ser definido, em apertada síntese como sendo "o percentual de elucidação (clearing), dentre as investigações encerradas, em determinado período de tempo"17.

Nesse ponto, entretanto, é importante temos em mente alguns pontos de partida:

- As taxas de elucidação variam amplamente entre as diferentes categorias de crimes. Assim, por exemplo: I) o tráfico de drogas normalmente tem taxas de elucidação mais elevadas porque a constatação do crime e a identificação do suspeito geralmente acontecem simultaneamente; II) nos crimes patrimoniais (furtos e roubos), por outro lado, as taxas de elucidação são geralmente baixas, situando-se entre $8 \%$ e $16 \%$ em todos os países; III) nos homicídios, os índices podem variar gravemente entre naçôes diversas e até mesmo dentro do mesmo país, independentemente do modelo investigativo adotado.

16 Eis justamente uma das principais vantagens, a nosso ver, do modelo do inquérito policial: reunir na mesma autoridade, o controle jurídico e operacional das respectivas atividades investigativas.

17 Trata-se, portanto, de um indicador de eficácia, não de eficiência. 
- Mesmo nos países que há muito já realizam algum tipo de estudo (a exemplo dos $\mathrm{EUA}^{18}$ ), os dados produzidos e divulgados pelos organismos policiais apresentam inconsistências. Afinal, é natural que exista certo clamor e pressão exercida pela sociedade e pelos escalões superiores das polícias a exigir a produção de bons resultados, com altas taxas de solução, sobretudo nos casos de homicídio. Nesse sentido, estudos recentemente divulgados demonstram imprecisões nos dados divulgados pelo $\mathrm{FBI}^{19} \mathrm{e}$ pelos Departamentos de Polícia de Chicago ${ }^{20}$ e Washington/DC ${ }^{21}$.

- Pelo mesmo motivo já acima mencionado, é importante notar que a chamada taxa de elucidação não traduz com exatidão apenas aqueles casos em que a autoria e a materialidade delituosas foram devidamente apuradas. Com efeito, órgãos policiais norte-americanos e de todo o mundo adotam critérios pelos quais uma investigação pode ser considerada "elucidada", sem que, no entanto, tenha-se, de fato, apontado o autor. A Polícia de Chicago/EUA, por exemplo, conta como "elucidados" (cleared) ou "solucionados" (solved), também aquelas situações em que: I) o suspeito faleceu; II) a vítima se recusa a prestar a queixa contra o suspeito; III) após encerrada a investigação, a promotoria opta por não adotar qualquer medida contra o suspeito,

18 O FBI realiza desde 1930 o programa denominado UCR (Uniform Crime Reporting), a partir dos dados encaminhados por cerca de 18.000 polícias em todo o país (federais, estaduais e locais).

19 Thomas Hargrove, em sua obra "Murder Mysteries", analisou os dados do FBI de mais de 185.000 homicídios não resolvidos entre 1980 e 2008 . Logo de início, descobriu que as forças policiais locais deixaram de informar ao FBI diversos casos e, utilizando a lei de acesso à informação norte-americana, ele reuniu detalhes de 15 mil casos adicionais de assassinatos não solucionados e que não constatam dessas estatísticas oficiais.

20 Isackson (2013) analisou as taxas oficiais de elucidação de homicídios ocorridos na cidade de Chicago entre 2008 e 2012 (56\% em 2008, 51\% em 2009, 2010 e 2011, e 37\% em 2012), porém, após uma acurada análise, verificou que as taxas eram, na verdade, ainda mais baixas que as divulgadas oficialmente (48\% em 2008, 44\% em 2009, 39\% em 2010, 34\% em 2011 e 26\% em 2012).

21 Em 2011, a Polícia de Washington divulgou uma taxa de elucidação de homicídios de 94\%. Uma taxa admirável (154\% superior que a de Boston e $104 \%$ mais alta que a de Baltimore para o mesmo ano), porém uma reportagem do Washington Post (25/02/2012) demonstrou que, em verdade, a taxa de solução de crimes teria sido de $57 \%$ para aquele ano, situações semelhantes teriam sido constatadas também entre os anos de 2007 e 2010 (“[...] an examination of District homicides found that the department's closure rate is a statistical mishmash that makes things seem much better than they are [...] The District had 108 homicides last year, police records show. A 94 percent closure rate would mean that detectives solved 102 of them. But only 62 were solved as of year's end, for a true closure rate of 57 percent, according to records reviewed [...] For 2010, she reported a 79 percent closure rate, but [...] the department solved 72 of 131 homicides that year, for a true rate of 55 percent. For 2009, [...] reported a rate of 76 percent, which would amount to about 110 of 144 cases. Records show that 67 of the 2009 cases, or 46 percent, were closed. For 2008, a 75 percent closure rate was reported, but the department closed 91 of 186 slayings that year, for a true rate of 49 percent. And for 2007, [...] reported a nearly 70 percent closure rate, but records show that 89 of the year's 181 homicides were closed, for a rate of 49 percent"). 
por não concordar com as conclusões da polícia ou considerar as provas insuficientes ${ }^{22}$ (Isackson, 2013).

- No Brasil, não existe um programa a semelhança do UCR, tampouco um padrão para a coleta e análise desses dados ${ }^{23}$. Os poucos dados disponíveis são provenientes de estudos e pesquisas autônomas, geralmente elaborados por cientistas sociais, assim como aqueles eventualmente divulgados pelos governos estaduais e federal por meio de suas Secretarias de Segurança Pública. Em geral, o que existe, quando existe, são dados relacionados apenas a taxa elucidação de crimes de homicídio.

Feitos esses esclarecimentos que julgávamos oportunos, a seguir apresentamos uma tabela com dados compilados de diversas fontes oficiais e autônomas, devidamente identificadas e que apontam para a taxa de elucidação de crimes em diferentes países.

Cientes das limitações e das diferentes peculiaridades entre as nações e mesmo entre organismos policiais de um mesmo país, já anteriormente referidas, a ideia é demonstrar, se existe, de fato, diferenças substanciais entre as taxas de elucidação de crimes entre os diferentes modelos investigativos adotados.

Em outras palavras, o que se buscará a seguir é apresentar se, sob o ponto de vista exclusivo da taxa de elucidação de crimes, existe um modelo que se revela mais eficaz que os demais.

\begin{tabular}{|c|c|c|c|c|c|}
\hline PAÍ́S & $\begin{array}{c}\text { Cidade / } \\
\text { Estado }\end{array}$ & Modelo & $\begin{array}{c}\text { \% Crimes } \\
\text { Totais }\end{array}$ & \% Homicídios & FONTE \\
\hline EUA & California & MP & ----------- & $\begin{array}{c}2000 / 2013: \\
55,76 \%\end{array}$ & UCR/FBI \\
\hline EUA & Pensilvania & MP & ---------- & $\begin{array}{c}2000 / 2013: \\
70,5 \%\end{array}$ & UCR/FBI \\
\hline EUA & $\begin{array}{c}\text { Nova Iorque } \\
\left({ }^{*}\right)\end{array}$ & MP & ----------- & $\begin{array}{c}2000 / 2013: \\
38,88 \%\end{array}$ & UCR/FBI \\
\hline
\end{tabular}

22 Essas três situações, dentre outras, são chamadas no jargão policial norte-americano de "ex-cleared" (cleared excepcionally) e, apenas como exemplo, no ano de 2012, representaram $11 \%$ de todos os homicídios solucionados pela Polícia de Chicago (CPD), ou seja: dentre 132 casos solucionados pela CPD (de um total de 507 homicídios ocorridos, o que dá uma taxa de solução de 26\%), 15 foram considerados elucidados pelos critérios "ex-cleared” (Isackson, 2013).

23 Tramita, entretanto, na Câmara dos Deputados, o Projeto de Lei (PL) 8122/14, que tornaria obrigatória a inclusão da taxa de elucidação criminal no Sistema Nacional de Informações de Segurança Pública, Prisionais e Sobre Drogas (Sinesp) - desenvolvido para armazenar informações sobre segurança pública, sistema prisional, execução penal e enfrentamento do tráfico de drogas em todo o país. 


\begin{tabular}{|c|c|c|c|c|c|}
\hline PAÍ́S & $\begin{array}{l}\text { Cidade / } \\
\text { Estado }\end{array}$ & Modelo & $\begin{array}{l}\text { \% Crimes } \\
\text { Totais }\end{array}$ & \% Homicídios & FONTE \\
\hline EUA & $\begin{array}{l}{ }^{*} \text { Todo o } \\
\text { país* }\end{array}$ & MP & $2010: 21 \%^{\# 1}$ & $\begin{array}{c}\text { 2000/2013: } \\
57,22 \%\end{array}$ & UCR/FBI \\
\hline EUA & $\begin{array}{l}\text { Chicago/ } \\
\text { Illinois }\end{array}$ & MP & -.--_-.--.--. & $\begin{array}{l}\text { 2008: } 48 \% \\
\text { 2009: } 44 \% \\
\text { 2010: } 39 \% \\
2011: 34 \% \\
2012: 26 \%\end{array}$ & $\begin{array}{c}\text { ISACKSON } \\
\text { (2013). }\end{array}$ \\
\hline EUA & $\begin{array}{l}\text { Detroit / } \\
\text { Michigan }\end{array}$ & MP & & 2012: 9\% & $\begin{array}{c}\text { MUR- } \\
\text { DERDATA } \\
(2015)^{\# 2}\end{array}$ \\
\hline EUA & $\begin{array}{c}\text { Nova } \\
\text { Orleans / } \\
\text { Lousiana }\end{array}$ & MP & & 2012: 15\% & $\begin{array}{l}\text { MUDERDA- } \\
\text { TA (2015) }\end{array}$ \\
\hline EUA & $\begin{array}{l}\text { Winsconsin } \\
{ }^{*} \text { Todo o } \\
\text { Estado }\end{array}$ & MP & & $\begin{array}{c}\text { 2008-2013: } \\
76,31 \%\end{array}$ & $\begin{array}{l}\text { MURDER- } \\
\text { DATA (2015) }\end{array}$ \\
\hline $\begin{array}{l}\text { Irlanda do } \\
\text { Norte }\end{array}$ & $\begin{array}{l}\text { *Todo o } \\
\text { país* }\end{array}$ & IPL & $\begin{array}{c}\text { 2007-2008: } \\
20.5 \%\end{array}$ & $\begin{array}{c}\text { 2006-2007: } \\
73,9 \% \\
2007-2008: 64 \%\end{array}$ & PSNI \\
\hline México & $\begin{array}{l}\text { *Todo o } \\
\text { país* }\end{array}$ & MP & -..-- & $\begin{array}{c}2009: 27.7 \% \\
2010: 19,4 \% \\
2012: 16 \% / \\
2 \%{ }^{\# 3}\end{array}$ & \\
\hline França & $\begin{array}{l}\text { *Todo o } \\
\text { país* }\end{array}$ & Juizado & $\begin{array}{c}2000: \\
26,75 \%^{\# 4}\end{array}$ & $\begin{array}{c}2007: 87,53 \% / \\
55,17 \%^{* 5}\end{array}$ & DGPN \\
\hline Uruguai & $\begin{array}{l}{ }^{*} \text { Todo o } \\
\text { país* }\end{array}$ & Juizado & -.--- & $\begin{array}{l}\text { 2011: } 80 \% \\
\text { 2014: } 52 \%\end{array}$ & $\begin{array}{l}\text { PERFIL } \\
(2015)\end{array}$ \\
\hline Itália & $\begin{array}{l}\text { *Todo o } \\
\text { país* }\end{array}$ & MP & -.---.-- & 2003: $62,3 \%$ & EURES \\
\hline Brasil & $\begin{array}{l}\text { Caxias do } \\
\text { Sul/RS }\end{array}$ & IPL & - & 2015: 60\% \#6 & \\
\hline Brasil & $\begin{array}{l}\text { Rio Grande } \\
\text { do Sul } \\
{ }^{*} \text { Todo o } \\
\text { Estado }\end{array}$ & IPL & -.--.--.--.-- & 2013: 70\% & \\
\hline Brasil & $\begin{array}{l}\text { Distrito } \\
\text { Federal }\end{array}$ & IPL & 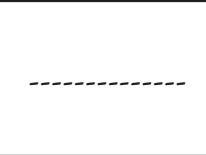 & $\begin{array}{c}\text { 2003-2007: 69\% } \\
2015: 90 \%\end{array}$ & $\begin{array}{c}\text { COSTA } \\
(2009) \text { e SSP/ } \\
\text { DF }\end{array}$ \\
\hline Brasil & $\begin{array}{l}\text { Aracaju / } \\
\text { Sergipe }\end{array}$ & IPL & .....- & $\begin{array}{c}2008: 72,9 \% \\
2013: 70,61 \%\end{array}$ & \\
\hline
\end{tabular}




\begin{tabular}{|c|c|c|c|c|c|}
\hline PAÍS & $\begin{array}{c}\text { Cidade / } \\
\text { Estado }\end{array}$ & Modelo & $\begin{array}{c}\text { \% Crimes } \\
\text { Totais }\end{array}$ & \% Homicídios & FONTE \\
\hline Brasil & $\begin{array}{c}\text { Ribeirão } \\
\text { Preto, } \\
\text { Franca, São } \\
\text { Carlos e } \\
\text { Araraquara/ } \\
\text { SP }\end{array}$ & IPL & - & 2012: $58 \%^{\# 7}$ & $\begin{array}{c}\text { FOLHA } \\
(2013)\end{array}$ \\
\hline Brasil & $\begin{array}{c}\text { Florianópo- } \\
\text { lis/SC }\end{array}$ & IPL & & $\begin{array}{c}\text { 2012: } 70,49 \% \\
\text { 2013: } 85 \% \\
\text { 2014: } 78 \%\end{array}$ & \\
\hline Brasil & $\begin{array}{l}\text { Rio de } \\
\text { Janeiro } \\
{ }^{*} \text { Todo o } \\
\text { Estado }\end{array}$ & IPL & -.-.-.-.-.-.-.- & $\begin{array}{c}\text { 1992: } 8 \% \\
\text { 2000-2005: } 14 \% \\
\text { 2010: } 27,5 \%\end{array}$ & $\begin{array}{l}\text { SOARES } \\
\text { (1996); MIS- } \\
\text { SE (2006) e } \\
\text { SSP/RJ. }\end{array}$ \\
\hline Brasil & Araxá/MG & IPL & & $\begin{array}{c}\text { 2013-2014: } \\
90 \%{ }^{\# 8}\end{array}$ & $\begin{array}{c}\text { Portal G1 } \\
(2014)\end{array}$ \\
\hline
\end{tabular}

Tabela 1 - Taxas de elucidação de crimes em diferentes países e sistemas investigativos

\section{Notas INSERIdAS NA TABELA}

\#1 Em consultas ao sítio eletrônico do UCR/FBI, obtiveram-se os dados de taxa de elucidação para todos os crimes (violentos e patrimoniais) para o ano de 2010. Apenas para referência, foram tabulados os referidos dados, conforme abaixo:

\begin{tabular}{|c|c|c|c|}
\hline & Crimes Violentos & Crimes Patrimoniais & Total \\
\hline Crimes conhecidos & 1.080 .242 & 8.064 .964 & 9.145 .206 \\
\hline Crimes elucidados (incluso "ex-clear") & 509.874 & 1.475 .888 & 1.985 .763 \\
\hline Taxa de Elucidação & $47 \%$ & $18 \%$ & $21 \%$ \\
\hline
\end{tabular}

\#2 O "MURDERDATA" é um banco de dados desenvolvido por Thomas Hargrove a partir da metodologia anteriormente adotada por ele para a elaboração do relatório "Murder Mysteries", constante de nossas referências. Ele permite fazer análises e mapas a partir de dados de dados do UCR-FBI. Está disponível em: http:// murderdata.blogspot.com.br/.

\#3 As taxas de elucidação divergem pois no primeiro caso se considerou apenas os casos em que foi identificado e preso algum suspeito (16\%) e, no segundo, apenas os casos em que houve efetiva condenação (2\%). O paranorama mexicano é muito grave, conforme se infere a seguir: "las estadísticas [...] revelan que las entidades con menor efectividad en la resolución de homicidios dolosos fueron San Luis Potosí y Morelos. En la primera entidad, nunca fueron aprehendidos los responsables de $99.6 \%$ de los 657 asesinatos. En la segunda, igualmente, $99.6 \%$ de los autores de 862 homicidios permanecen prófugos o no identificados. Además de los ya mencionados, la lista de los 10 estados con mayor grado de homicidios en los que el autor es desconocido o prófugo, está integrada por Zacatecas y Durango (99.5\% de los homicidios); Guerrero (99.3\%); Quintana Roo, Sinaloa y Oaxaca (99.2\%)" (MARTINEZ, 2013).

\#4 Esse dado engloba tanto a taxa de elucidação da Políce Nationale (23,10\%) como da Gendarmerie (37,24\%). A diferença nas taxas de elucidação mereceria uma análise mais aprofundada, porém, em princípio, cremos se justifica em boa parte pelo fato de a Nationale ser uma polícia urbana, que atua em Paris e imediações, combatendo, com mais frequência um maior número de crimes mais graves e violentos, ao passo que a Gerdarmerie atua nas cidades menores da França, onde há incidência menor de crimes graves e, pelo seu menor volume de 
trabalho (a Gendarmerie apurou menos de 1 milhão de delitos em 2000, ou seja, cerca de 1/3 de todos os delitos ocorridos na França naquele ano) a própria apuração dos delitos que ocorrem seja mais fácil. Note-se que no referido relatório da DGPN (2000) não foram especificadas as taxas de elucidação por tipo de crime.

\#5 No total, foram cerca de 800 homicídios na França no ano de 2007, além de cerca de 1000 tentativas. Em números absolutos, a taxa de elucidação foi de $87,53 \%$, porém, é interessante registrar que as autoridades francesas reconhecem que os homicídios possuem diferentes graus de complexidade na apuração conforme sua motivação. Quando se tratam de homicídios praticados pelo acerto de contas entre criminosos, por exemplo, a taxa de elucidação caiu para 55,17\%. Nesse sentido: "Le taux d'homicides non élucidés varie fortement selon le type d'homicides. Ainsi, il est de 55,17\% pour les homicides commis à l'occasion de règlements de compte entre malfaiteurs alors qu'il n'est que de $11,46 \%$ pour les homicides pour d'autres motifs qui constituent la catégorie d'homicides la plus importante, ou encore de $8,57 \%$ pour les homicides pour vols ou à l'occasion de vols" (Ministre de la Justice, 2008).

\#6 Dados referentes apenas ao primeiro semestre de 2015.

\#7 De 150 homicídios, 88 foram solucionados

\#8 Entre novembro de 2013 e outubro de 2014 ocorreram 23 homicídios na cidade, dos quais 22 solucionados e um ainda se encontrava em andamento à época da reportagem (G1, 2014).

Das informaçóes acima coligidas, verifica-se que as taxas de elucidação de crimes, sobretudo homicídios, independem do modelo adotado, variando, bastante, até mesmo dentro de um mesmo país.

Com efeito, em que pesem as críticas feitas ao inquérito policial, é interessante registrar que diversas delegacias de Polícia Civil, no Brasil têm obtido, nesses últimos anos, inegáveis avanços e excelentes resultados no combate a esse tipo de ilícito, superiores até aos índices obtidos historicamente em países ditos de $1^{\circ}$ mundo.

Em sentido contrário, sistemas que eventualmente são sugeridos pelos opositores do inquérito policial não demonstraram ser mais eficientes naqueles países que, nestes últimos anos, passaram a enfrentar graves problemas relacionados ao narcotráfico, à pobreza e ao crescimento e recrudescimento da violência urbana, como se pode verificar da queda (em alguns casos vertiginosa) nas taxas de elucidação enfrentadas no Uruguai (que adota o juizado de instrução), no México e em cidades norte-americanas como Chicago e Nova Iorque (que adotam, por seu turno, o sistema do promotor-investigador $)^{24}$.

No caso norte-americano, aliás, a queda na solução de homicídios é evidente nestes últimos trinta anos, como demonstra o gráfico a seguir:

24 Nesse mesmo sentido, os premiados estudos de Thomas Hargrove (Murder Mysteries, 2011) apontaram que "Police solved only 35 percent of the murders in Chicago in 2008, 22 percent in New Orleans and just 21 percent in Detroit. Yet authorities solved 75 percent of the killings that same year in Philadelphia, 92 percent in Denver and 94 percent in San Diego". 


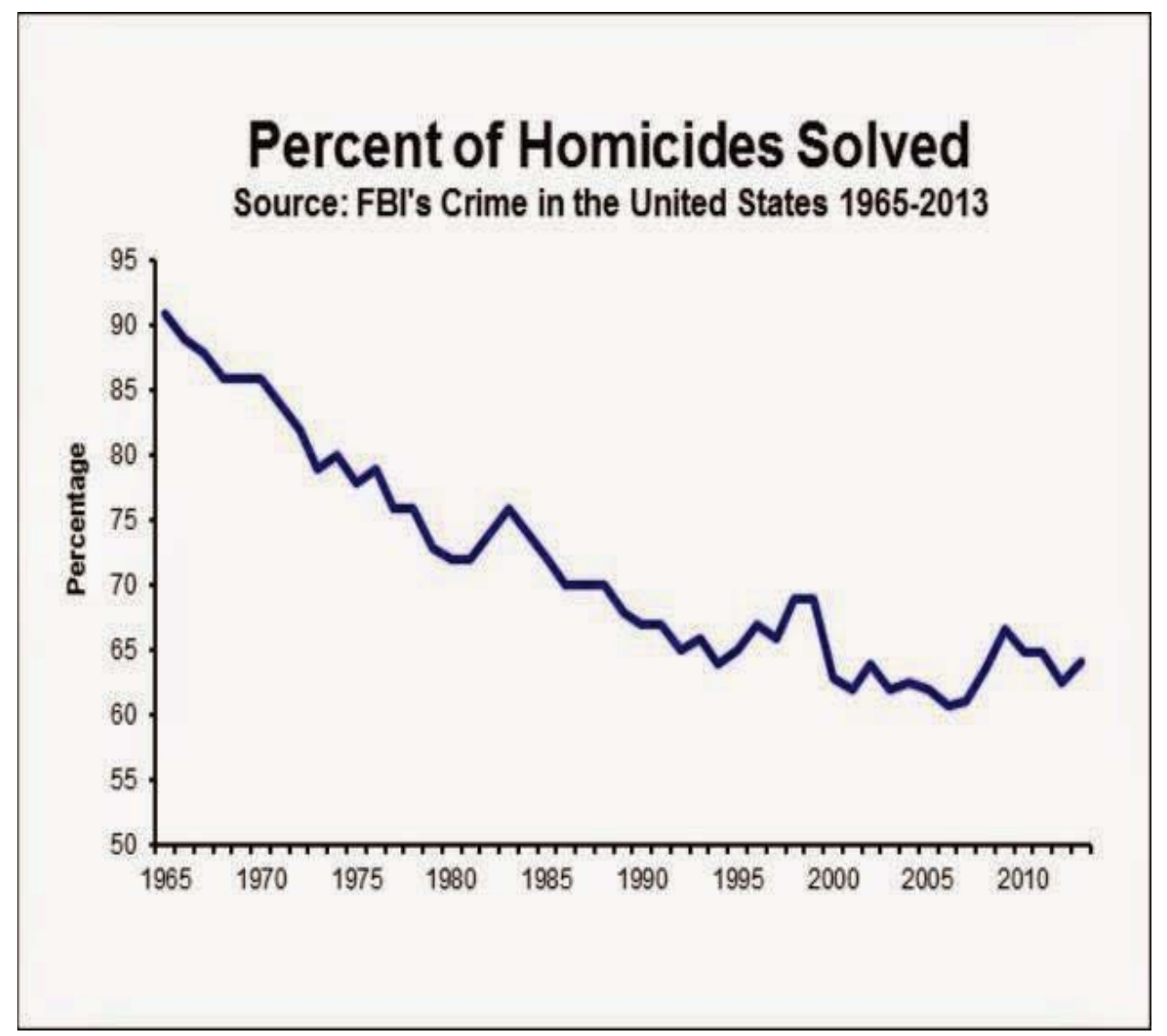

Figura: 1- Homicídios Elucidados nos EUA - 1965/2010 (MURDERDATA, 2015).

Note-se que esse gráfico se baseia em dados gerais dos EUA e que em cidades como Chicago, Detroit e Nova Orleans a queda foi ainda mais abrupta, conforme os dados já anteriormente exibidos ${ }^{25}$.

Mas se tudo isso nada tem a ver com o modelo investigativo adotado, porque, então, ocorre?

Uma resposta plausível é a que se extraí dos ensinamentos do Prof. Jorge Felipe de Lima Dantas, da UNB, a comentar os resultados da pesquisa levada a efeito:

[...] nos EUA, as taxas já disponiveis de esclarecimento de homicídios para 2007 [...] apontam uma queda de 91\% de esclarecimentos em 1963, para 61\% em 2007 [...] uma redução linear

25 Com efeito, uma rápida olhada nos dados disponíveis no MURDERDATA demonstra em que pese a média norte-americana se manter acima da brasileira (entorno de 65\%), o fato é que lá, as taxas de elucidação, principalmente em cidade maiores, continuaram a cair nestes últimos 05 anos, enquanto por aqui, apesar dos poucos dados disponíveis, verifica-se, ainda que pontualmente, um acréscimo nessas taxas, inclusive em capitais tidas como violentas. 
total de 30\%, ou anual de cerca de 0,7\%, em uma série histórica de 44 anos. A situação [...] considerando cidades de mais um milhão de habitantes, também de acordo com o FBI, aponta niveis de esclarecimento que caem de $89 \%$ para 59\%, respectivamente em 1963 e 2007, novamente mostrando um diferencial para menos de 30\% [...] Ora, se o objeto é o mesmo e a metodologia de estudo foi mantida constante (e tudo indica que foi...), é de supor que o fenômeno criminológico (incluidos entre seus objetos de estudo o crime propriamente dito, os criminosos seus autores e questóes conexas como é o caso da taxa de esclarecimentos) no qual o delito do homicídio está inserido deva ter sofrido alguma transformação, [...] E é exatamente isso o que intuem os membros da comunidade policial norte-americana, referindo um incremento nas mortes por homicídio motivadas pela atividade do narcotráfico, mortes essas ocorridas geralmente em circunstâncias impessoais e anônimas [...] Aumentam, assim, os casos não-esclarecidos, pela própria natureza do fenômeno [...] (DANTAS, 2009).

\section{E arremata o mesmo autor:}

Passa a ser simplista e meramente ideológica a referência a uma pior qualidade do serviço policial para explicar taxas 'pequenas' de esclarecimento de homicidios, tanto no Brasil quanto albures. A tendência às 'baixas' taxas de esclarecimento de homicídios não é questionada nos EUA quanto à eficiência policial. E vale notar que lá existe uma respeitável comunidade de acadêmicos mundiais de justiça criminal (distribuida em mais de 17 mil organizaçôes profissionais do setor e em cerca de 700 programas acadêmicos de graduação da mesma área) [...] ao menos no que tange à questão da 'taxa de esclarecimento de homicídios no Brasil', o estudo apontado no CB não acrescenta muito ao que já é sabido no meio policial mundial, podendo fazer sugerir, em sua visão quiçá parcial do fenômeno dos homicídios e respectivos esclarecimentos, uma visão conclusiva parcial e por isso mesmo equivocada. Mais que isso ainda, ao apontar o IP como um procedimento burocrático desnecessário ou frágil, razão mesmo de 'taxas preocupantes' de esclarecimentos de homicídios, não consta que o estudo referido no $C B$ aborde a própria burocratização reinante no país como um todo, tampouco as alternativas politicas para escapar de tal 'macro-modelo. Debitar ao IP baixas taxas de esclarecimento passa a ser, assim, como 'culpar of feio pela feiura' (DANTAS, 2009).

Ainda nessa esteira de raciocínio, convém registrar, por oportuno, que se iniciou, no ano de 2014, um estudo piloto na Superintendência da Polícia Federal em Roraima não só para média a taxa de elucidação de crimes 
naquela regional, mas também para desenvolver um modelo estatístico que permitisse o cálculo de tal indicador de forma automática para todas as unidades da Polícia Federal.

O resultado foi animador. De todas as investigações encerradas no ano de 2014 pela Polícia Federal em Roraima, 70\% (setenta por cento) o foram de forma exitosa, sendo que em $40 \%$ (quarenta por cento) houve indicação de autoria e em 30\% (trinta por cento) concluiu-se pela inexistência de crime $^{26}$, o que por si só demonstra a relevância do inquérito policial não apenas para a apuração de ilícitos, mas também como filtro apto a evitar ações penais desnecessárias.

Ressalte-se, ainda, que um estudo preliminar, efetuado ao longo dos três primeiros meses de 2015, parece indicar que os índices da Polícia Federal como um todo não se distanciam em muito dos obtidos pela região de Roraima, variando entre $90 \%$ e $51 \%$

Levando-se em consideração que as taxas de elucidação dos crimes em geral na França, nos Estados Unidos e no Reino Unido, pelos dados já alhures apresentados, não superaram, via de regra, os 30\%, verifica-se que o inquérito policial realizado pela Polícia Federal, sob a presidência do delegado de polícia, permite resultados ainda superiores às polícias de outros países tidas como de $1^{\circ}$ mundo.

Por óbvio, tais análises de dados e respectivos estudos merecem continuidade e aprimoramento.

Da mesma forma, reconhecemos existir, ainda, diversos obstáculos a uma maior eficiência da atividade investigativa através do inquérito policial, o que tentaremos tratar, em linhas pouco mais que gerais no tópico a seguir.

Por outro lado, a luz de todas as conclusões extraídas até aqui, parece-nos óbvio que defender, pura e simplesmente, a mudança do inquérito policial para um sistema de investigação ministerial ou de juizado

26 Cremos que, em países como o Brasil, onde vigora o princípio da obrigatoriedade e, portanto, as autoridades policiais têm dever legal de iniciar uma investigação para cada fato que chega a seu conhecimento, a investigação criminal também exerce uma função social ao evitar que pessoas inocentes sejam submetidas ao strepidus judici. Desta forma, há que se considerar também como sucesso na investigação quando seu resultado apontar pela atipicidade da conduta ou, ainda, pela inexistência do fato, já que desta forma está se assegurando a um cidadão que ele não será injustamente submetido às agruras de um processo criminal na qualidade de réu. 
de instrução, pouco ou nada de útil ajudaria, hoje, no Brasil, na elucidação de mais crimes ${ }^{27}$.

\section{Alguns Obstáculos que se Apresentam a uma MAIOR EFICIÊNCIA do INQUÉRito Policial}

Em toda ou qualquer atividade humana, via de regra, se desejamos plena eficiência em nossa empreitada, não nos basta apenas conhecer os instrumentos de que dispomos, seu funcionamento, seus objetivos, destinatários e limites.

Mais do que isso: necessário se faz, também, conhecer os obstáculos que haveremos de enfrentar em nossa empreitada.

Nesta esteira de raciocínio, ainda que talvez de forma bastante incompleta, eis que, por si só, este tema poderia ser objeto de um estudo próprio, de fôlego e certamente bastante fecundo, optamos por encerrar nosso singelo estudo trazendo à tona aqueles que julgamos serem alguns dos principais obstáculos a um inquérito policial ainda mais eficiente, conforme a seguir.

\subsection{A AUSÊNCIA DE COOPERAÇÃO DOS DIFERENTES ÓRGÃOS NO INTERESSE DAS INVESTIGAÇÕES CONDUZIDAS NO BOJO DO IN- QUÉRITO POLICIAL}

O inciso VIII do artigo $3^{\circ}$ da Lei 12.850/13 prevê, expressamente, que, em qualquer fase da persecução penal, será permitida a "cooperação entre instituições e órgãos federais, distritais, estaduais e municipais na busca de provas e informações de interesse da investigação ou da instrução criminal”.

27 Apenas como exemplo, uma pesquisa amplamente divulgada pela mídia, e cujos dados foram efetivamente confirmados pelo próprio MPF, demonstrou que apenas $9,8 \%$ das investigações realizadas exclusivamente pelo Ministério Público Federal, entre os anos de 2009 e 2012, resultaram em processos criminais (FOLHA, 2014). Por outro lado, dados oficiais do Mato Grosso (SSP-MT, 2009) e do Distrito Federal (SSP-DF, 2015) apontam, respectivamente, para taxas de solução de homicídios entre $80 \%$ e $90 \%$. Estes dados, somados aos inegáveis avanços que obtivemos no combate ao crime organizado, sobretudo os crimes relacionados à corrupção e ao desvio de recursos públicos, demostram o contrário: o inquérito policial é, dentre os instrumentos investigativos hoje utilizados no Brasil, o que se afigura mais eficiente, desde, é óbvio, que as Polícias Judiciárias disponham de efetivo e recursos adequados. Falaremos disso mais adiante, em tópico específico. 
Pouco ou nada tratada pela doutrina especializada, a expressa previsão de cooperação entre órgãos e instituições públicas no interesse da produção de provas tanto no inquérito como em juízo veio em momento muito oportuno, porém é ainda muito pouco utilizada.

Afinal, no curso de numerosas investigações, como naquelas que envolvem fraudes documentais ou ideológicas perante os diversos órgãos da administração direta e indireta (fisco, previdência, órgãos ambientais, agências de fomento, licitações, órgãos de trânsito etc.) é cada vez mais comum que os ilícitos se afigurem de tal forma bem engendrados e complexos que a efetiva materialização dos delitos demanda muito mais que o bom e velho tirocínio policial aliado aos áudios e dados interceptados ${ }^{28}$.

Com efeito, uma boa compreensão do universo e das práticas rotineiras no âmbito de um determinado órgão público, o acesso a seus diversos bancos de dados e até mesmo documentos físicos (o que é preciso seja feito sem atrair as atenções e olhares dos suspeitos) são ferramentas indispensáveis à melhor compreensão e qualificação dos dados obtidos no curso do inquérito policial. Da mesma forma, o acesso irrestrito e capacitação no manuseio de diferentes sistemas e bancos de dados da administração pública (federal, estadual ou municipal) pode se revelar fundamental. Em outras palavras, a análise desses dados, em alguns casos, exigirá o auxílio de órgãos e servidores externos à Polícia Judiciária, a fim de podermos efetivamente compreender e avaliar a vasta gama de informações produzidas.

Ocorre, entretanto, que todos esses conhecimentos e habilidades específicas não podem estar dissociados da linha investigativa adotada pelo delegado de polícia, responsável por coordenar tais trabalhos, de forma isenta e imparcial, tampouco deixarem de ser analisados em conjunto com outros dados, informações e conhecimentos de natureza tipicamente policiais, sob pena de operar-se, in casu, verdadeiro desvirtuamento dos fins, objetivos e até mesmo dos lindes jurídico-constitucionais do inquérito policial, tal como delineados no ordenamento pátrio. ${ }^{29}$

Em outras palavras: a cooperação, tal qual prevista neste dispositivo, se revela fundamental justamente por permitir conciliar os interesses e

$28 \mathrm{Na}$ verdade, a interceptação telefônica, raramente se afigura em prova da materialidade de qualquer ilícito (a exceção, obviamente, são os ilícitos que se consumam pela simples palavra, escrita ou falada). Trata-se, muito mais, de um instrumento de direção das investigações, a indicar o norte a ser seguido pela autoridade policial.

29 Da mesma forma, não há dúvida que eventuais provas ou informações que demandem a colaboração com outros órgãos, já na fase da instrução processual em juízo, serão realizadas, por seu turno, em estrita consonância com as determinações emanadas da autoridade judiciária competente. 
clamores maiores da sociedade, na busca por uma investigação criminal cada vez mais eficiente e completa, congregando, quando necessário, as diferentes expertises que se façam necessárias ao esclarecimentos dos fatos em sua mais ampla dimensão, sem, contudo, perdemos de vista os direitos e garantias constitucionalmente assegurados ao suspeitos e demais envolvidos, dever inarredável da autoridade policial, que por expressa determinação legal coordena tais trabalhos. ${ }^{30}$

Note-se que o eventual servidor de outros órgãos que foi designado para colaborar, nesses casos, atua em apoio às atividades de Polícia Judiciária $^{31}$, em legítima posição de agente da autoridade ${ }^{32}$, sob sua coordenação e responsabilidade ${ }^{33}$.

30 Como já referido anteriormente, tal medida, no curso das interceptações, não se confunde com o compartilhamento de provas, que atende a interesses e objetivos totalmente distintos (o de que as provas produzidas por meio de interceptações telefônicas, devidamente autorizadas em processo criminal, possam, posteriormente, ser utilizados como prova emprestada em processos administrativos a cargo dos respectivos órgãos, ou ainda para instruir ações de natureza civil, como a própria Ação Civil Pública, a cargo do MP). Ora, se o compartilhamento em si, mesmo na interceptação devidamente autorizada no curso de inquérito policial, realizada pela Polícia Judiciária, exige específica e circunstanciada autorização judicial, com muito mais razão deverá a participação de agentes de órgãos outros (RFB, IBAMA, CVM, TCU etc.) no curso de tais diligências investigativo-criminais exigir uma respectiva e também circunstanciada autorização judicial. Ousamos, aliás, dizer que esse tipo de medida somente poderá se dar, no caso concreto, caso o próprio delegado de polícia responsável pelos trabalhos investigativos entenda sua pertinência e necessidade, bem como esclarecendo-se que o papel desses servidores especializados será desempenhado sob a coordenação e reponsabilidade da autoridade policial, a quem estarão, nos termos da respectiva decisão judicial e do termo de compromisso específico lavrado nos autos, subordinados até o final de seus trabalhos. Isto é necessário para que evitemos duas graves ilegalidades: i) que as interceptações passem a ser realizadas em dissonância com a linha investigativa adotada e direcionadas a fins outros que não o da investigação criminal (buscando-se, assim, por via transversa, utilizar-se da interceptação para fins administrativos, por exemplo); ii) pessoas não autorizadas e compromissadas judicialmente, estranhas à equipe investigativa, tenham acesso aos áudios e dados produzidos, com sérias e graves implicações não apenas à investigação em si, mas às próprias garantias e direitos individuais dos investigados e seus eventuais interlocutores).

31 A cooperação difere, em muito, das famosas "forças-tarefa". Isto porque, nas forças-tarefa, existe uma união de esforços e recursos, mas cada órgão atua com relativa autonomia e dentro de suas atribuições institucionais para a solução de um problema comum, por meio de operações conjuntas. Na prática, a "Força-tarefa" funciona bem e na exata medida que todos os órgãos envolvidos compartilhem interesses comuns de reprimir ou atuar em face de um determinado ilícito em suas respectivas esferas de atuação, mas se torna inadequada no curso de trabalhos que interessam apenas a uma das partes, ou que esbarrem em restriçôes legais à troca de informações. É uma forma inteligente de se solucionar limitações logísticas, de pessoal e reprimir uma gama variada de ilícitos criminais e administrativos concomitantemente. A cooperação, por seu turno, é feita no interesse da investigação ou do processo criminal (art. $3^{\circ}$, inciso VIII, da Lei 12.850/13). Independe, portanto, de haver interesse do órgão que coopera, e se justifica, justamente, no dever de colaboração com a Justiça (art. 339 do CPC).

32 Atua, portanto, como "longa manus" ou "órgão-meio" à disposição do delegado de polícia, titular do Estado-investigação. Trataremos deste assunto mais detidamente no item 3.5.

33 Registre-se que a cooperação entre a Polícia Judiciária e outros órgãos e instituições no curso das 


\subsection{Estrutura e funcionamento do Sistema de Justiça CRIMINAL E A NECESSIDAdE DE MODERNIZAÇÃO E SIMPLIFICA- ÇÃo doS PROCEDIMENTOS E ATOS PROCESSUAIS}

Um Judiciário eficiente e respeitado é um dos alicerces da estabilidade econômica, politica e social. No Brasil, ocorre que o Judiciário não tem uma imagem positiva. Fala-se, com frequência, de sua ineficácia e lentidão, e acredita-se mesmo que esteja em crise [...] As deficiências de recursos humanos, acrescidas de procedimentos processuais arcaicos, geram a morosidade dos cartórios, o que, por sua vez, é parte permanente de favores e irregularidades diversas. Assim, à necessidade de uma nova gestão profissional e de adequados critérios de recrutamento e treinamento de pessoal para as atividades administrativas, soma-se a indispensável modernização dos procedimentos e rotinas processuais - arena em que se destaca, por sua importância, a informatização processual. Sem a solução desse gargalo, não há como dotar o Judiciário da celeridade que os novos tempos requerem. (MACHADO, 2006).

Do trecho acima, infelizmente, resta claro que o Poder Judiciário brasileiro ainda não corresponde aos anseios de uma justiça célere e eficaz. ${ }^{34}$

Por óbvio, o panorama não se revela muito diverso nos demais órgãos que compõem o sistema de justiça criminal lato sensu, notadamente as polícias judiciárias e o Ministério Público.

Cremos, sinceramente, que a carga de trabalho do reduzido número de juízes, promotores e autoridades policiais poderia ser aliviada pela modernização e simplificação dos procedimentos e atos processuais, principalmente pelo uso de novas tecnologias ${ }^{35}$ bem como pela delegação de competências e atribuições para a realização de alguns atos por parte de funcionários quali-

investigações não se restringe apenas nos casos em que haja medidas de interceptação telefônica ou telemática, podendo se estender a uma gama variada de medidas investigativas, em variadas circunstâncias. Não por acaso, o novel diploma previu expressamente, como meio de prova, "cooperação entre instituições e órgãos federais, distritais, estaduais e municipais na busca de provas e informações de interesse da investigação ou da instrução criminal” no inciso VIII de seu art. $3^{\circ}$, o qual trataremos de forma específica e detalhada oportunamente.

34 Não raro (e aqui valemo-nos de nossa experiência pessoal) pedidos e representações feitas por autoridades policiais no interesse de investigações que versam sobre o crime organizado levam semanas e até meses para serem apreciados e julgados.

$35 \mathrm{O}$ uso da videoconferência na realização de oitivas e interrogatórios, assim como no cumprimento de precatórias, bem como a digitalização e integração num mesmo sistema de processos, procedimentos e inquéritos policiais revelam-se de fundamental importância nesse sentido. 
ficados, direcionando-se, dessa forma, as atividades das respectivas autoridades apenas para os atos que, verdadeiramente, lhe cabem com exclusividade.

O âmbito da Polícia Judiciária é sabido que diversos estados já utilizam procedimentos eletrônicos, é necessário, porém ir mais adiante, inclusive com a integração de bases de dados e troca mais célere de informações ${ }^{36}$.

\subsection{Desarmonia ENTRE OS ÓRgãos QUe INTEgRaM A "PERSE- CUTIO CRIMINIS EXTRA JUDITIO” E A NECESSIDADE DE AUTO- Nomia para a Polícia Judiciária}

Muitas investigações criminais seriam mais céleres e eficientes se houvesse uma melhor compreensão e exercício, por cada dos personagens que integram a persecução criminal (Parquet, Poder Judiciário e Polícia Judiciária), de seus respectivos papéis, atribuições e competências legais.

É exemplo dessa desarmonia as recentes tentativas do Parquet de assumir, ele próprio, a direção da investigação criminal, não apenas por meio de investigações autônoma, mas também por meio da direção das investigações conduzidas por meio de inquérito policial, ao argumento que, por se tratar do titular da ação penal, seria ele também o órgão destinatário exclusivo do inquérito e quem deveria dizer, em última instância, o que deverá ser feito ou não no bojo do respectivo inquérito.

Também, temos visto, nestes últimos anos, movimento crescente que busca, cada vez mais, reduzir a participação do magistrado na fase do inquérito policial, sobretudo na esfera federal ${ }^{37}$, ao argumento de que a in-

36 Chega a causar estranheza que, em plena era da informação, as precatórias expedidas pelas autoridade policiais ainda sejam enviadas e recebidas por meio de documentos físicos, não existindo um sistema eletrônico para isso.

37 Neste sentido, apesar da expressa previsão legal no art. 10 do CPP, foi editada a Resolução CJF 63, de 26.06.2009, que afastou o controle jurisdicional do inquérito e determinou o trâmite direto entre os apuratórios da Polícia Federal para o Ministério Público Federal. A ideia era conferir maior celeridade ao trâmite dos apuratórios que, doravante, iriam diretamente ao Ministério Público para apreciação e concessão de eventuais dilações de prazo. O argumento esposado na resolução é a de que a tramitação com o Poder Judiciário não estaria de acordo com o sistema acusatório, esposado na CF/88. Ironicamente, nos parece que é justamente o contrário: ao se afastar das investigações e "delegar" a dilação dos prazos ao Ministério Público, o que se prestigia é um sistema estritamente inquisitivo, em que a investigação preliminar é vista como simples preparação para a acusação. De fato, o que se verificou na sequência, é o quase que total afastamento das autoridades judiciárias federais das investigações, com inegável enfraquecimento do controle jurisdicional do inquérito, hoje circunscrito, exclusivamente, à apreciação de cautelares. 
vestigação criminal serve à formação da opinio delicti do Parquet e, portanto, em respeito ao sistema acusatório, deveria ser atribuído ao magistrado, apenas aquelas tarefas relacionadas ao deferimento de cautelares, de forma a lhe preservar a imparcialidade que, aliás, se destaca sobremaneira dentre os seus principais atributos.

Tal entendimento é deveras equivocado, pois o afastamento da autoridade judiciária do controle da investigação, reforçando, uma suposta posição de superioridade do órgão-acusador em relação aos demais atores (advogados, investigado e o próprio delegado), longe de tornar a investigação criminal mais acusatória, lhe reserva dois lugares de honra no terreno da inquisitoriedade.

Outro grave equívoco que se verifica é o entendimento, isolado e minoritário ${ }^{38}$, felizmente, de que as medidas cautelares deferidas no curso das investigações seriam preparatórias do futuro processo penal ${ }^{39} \mathrm{e}$, portanto, apenas o MP seria legitimado processual para requerê-las, negando-se, por conseguinte, poderes de representação autônoma e direta pelo delegado de polícia ${ }^{40}$.

Sobre o assunto, que, aliás, extrapola em muito os estreitos limites deste trabalho, remetemos o leitor ao excelente artigo de lavra do Prof. Eduardo Luiz Santos Cabette, constante de nossas referências e, cujos trechos a seguir transcritos, cremos serem bastante elucidativos:

Admitir que o Juiz não possa deferir cautelares por representação direta da Autoridade Policial porque somente com o aval do Ministério Público isso pode ocorrer, justamente pelo fato de este ser o titular da ação penal e ser o unico com legitimidade para aferir se haverá ou não ação penal, levaria, por via de consequência a deslegitimar também a avaliação judicial quanto ao cabimento ou não de uma ação penal. Será que o Juiz não poderia mais rejeitar uma denúncia? Não poderia mais indeferir uma cautelar encampada pelo Ministério Público partindo da Autoridade Policial ou reque-

38 Nesse sentido: MENDONÇA, Andrey Borges de. Prisão e outras medidas cautelares

$39 \mathrm{Em}$ verdade, esse entendimento desconsidera que as diversas medidas cautelares, mesmo as prisões processuais e buscas deferidas no curso das investigações, são deferidas não no interesse do futuro processo (tais como as cautelares preparatórias), mas no interesse da própria investigação criminal.

40 A questão é de tal forma tratada que, chega-se a propor que, caso o magistrado acate a representação firmada pelo delegado de polícia, não apenas sem ouvir o MP, mas, ainda que ouvindo, decidindo contrariamente à manifestação ministerial, tal decisão seria nula (MENDONÇA Apud CABETTE, 2013). 
rida diretamente por aquele? Ora, se é o Ministério Público quem dá a palavra final sobre o futuro Processo Penal, sendo defeso ao magistrado qualquer atuação que o contrarie, tudo isso é consequência natural.

Também é descabido afirmar que a atuação da Autoridade Policial no Inquérito deve reduzir-se a coletar informes para o Ministério Público (pólo acusador). Isso é, infelizmente, um dos reflexos do pauperismo ou indigência do estudo do Inquérito Policial no Brasil. Essa falta de conbecimento acerca da real abrangência da investigação criminal é responsável por uma visão deturpada porque reducionista e parcial desse importante instrumento da persecução criminal. O Inquérito Policial não é e jamais será instrumento a serviço do Ministério Público ou do Querelante somente, mas sim da busca da verdade processualmente possivel de forma imparcial, dentro da legalidade. O Delegado de Polícia não deve produzir ou colher provas e indicios somente voltados para a acusação, mas sim de forma genérica, primando pela total apuração dos fatos, venha isso a beneficiar a defesa do suspeito ou a incriminá-lo [...] Nesse passo, por mais que se considere a atuação escorreita dos membros do Ministério Público, primando por uma posição de fiscalização da legalidade (aliás, uma de suas funções institucionais), não é desejável que todo o poder de decisão acerca do cabimento ou não de uma cautelar fique concentrado nesse órgão que, quer se queira ou não, atuará eventualmente no polo acusador do futuro processo. Vedar a representação pela Autoridade Policial (uma Autoridade que pode e deve ser imparcial, exatamente porque jamais postulará ou sustentará defesa ou acusação em juizo) ou mesmo condicionar sua validade ao parecer ministerial é, isso sim, violar não somente o Sistema Acusatório, mas também de um só roldão a ampla defesa e a isonomia processual. É justamente o fato de ser o Ministério Público o titular da ação penal pública que indica que sua atuação deve ser sempre opinativa ou de requerimento e jamais deve subordinar de qualquer forma (positiva ou negativa) a decisão judicial. Aliás, "decisão"é somente a Judicial, cabe ao Ministério Público e demais atores processuais opinar e pedir. Não se podem confundir as funções jurisdicionais com as funçôes ministeriais (CABETTE, 2013).

Vamos, aliás, um pouco além. Ousamos dizer que, em verdade, a manifestação ministerial no caso das cautelares representadas diretamente pelo Estado-investigação, se deve não à sua posição do MP como futura parte na 
ação penal, mas, decorre e deve ser, sempre, interpretada à luz de sua função institucional como custos legis ${ }^{41}$.

Destarte, cremos, sinceramente, fazer-se necessário, urgentemente, que os demais operadores do Direito (juízes, membros do Parquet e advogados) compreendam o verdadeiro papel desempenhado pelo Polícia Judiciária, o Delegado de Polícia e o inquérito policial no âmbito da persecução criminal.

\author{
Ademais, cremos já é passada a hora de conferir-lhe maior autono- \\ mia $^{42}{ }^{43}$ para que possa, efetivamente, desempenhar as suas funções de forma \\ célere e imparcial em estrita consonância com os ditames de um Estado De- \\ mocrático de Direito. ${ }^{44}$
}

41 Reforça esse entendimento a constatação de que a manifestação ministerial é prevista mesmo nos crimes de ação privada, não cogitando ou prevendo, sabiamente, a legislação em vigor, sob nenhuma hipótese, a necessidade de manifestação do ofendido ou quem tenha qualidade para representá-lo nesses casos. Com efeito, tais manifestações ministeriais se circunscrevem ao cabimento ou não da medida pleiteada sob o ponto de vista jurídico, legitima atividade de custos legis, diversamente do que ocorre quando o órgão requer, ele próprio a medida, por entender ela indispensável à sua opinio delicti. Note-se, entretanto, que por não ser o presidente da investigação (Estado-investigação), não saber a linha investigativa adotada e não ter familiaridade e experiência com esse tipo de atividade, o $\mathrm{MP}$, não raro, requer cautelares em momentos inoportunos, ou até mesmo medidas que podem trazer graves prejuízos à linha investigativa até então adotada. Uma prisão processual ou uma busca realizada em momento inoportuno pode colocar toda uma investigação a perder. Nessa esteira, reputamos seria de bom alvitre que, nos casos de medidas cautelares requeridas diretamente pelo MP, o delegado de polícia também fosse instado a se manifestar quanto à convencia e oportunidade da medida naquele momento da fase investigativa.. Nessa esteira de raciocínio, muito acertada, aliás, a nova Lei de Organizações Criminosas, ao prever a análise de requerimentos formulados pelo MP para a chamada “infiltração policial”, será precedida de manifestação do delegado de polícia.

42 Nesse sentido tramita, no Congresso Nacional, a PEC 412/2009. A proposição já passou pela Comissão de Constituição, Justiça e Cidadania (CCJC), sob relatoria do Deputado Vieira da Cunha, com parecer do relator pela admissibilidade, com substitutivo: "Art. $1^{\circ}$ Esta Emenda Constitucional altera a redação do $\$ 1^{\circ}$ do art. 144 da Constituição Federal, dispondo sobre a organização da Polícia Federal. Art. $2^{\circ} \mathrm{O} \$ 1^{\circ}$ do art. 144 da Constituição Federal passa a vigorar com a seguinte redação: Art. $144(. ..) \S 1^{\circ}$ Lei Complementar organizará a Polícia Federal e prescreverá normas para a sua autonomia funcional e administrativa e a iniciativa de elaborar sua proposta orçamentária dentro dos limites estabelecidos na lei de diretrizes orçamentárias, com as seguintes funções institucionais (...) Art. $2^{\circ}$ Esta Emenda Constitucional entra em vigor na data de sua publicação.”.

43 Por outro lado, é importante não confundirmos a autonomia administrativa e financeira da Polícia Judiciária com independência ou, pior, a ausência de controles, tanto internos como externos. Com efeito mesmo que aprovada a referida PEC a Polícia Judiciária e sobretudo o inquérito policial continuam a se submeter a todos os 07 controles já anteriormente referidos, constituindo-se, portanto, no sistema investigativo mais controlado em todo o mundo.

44 Estranhamente, muito embora os críticos da Polícia Judiciária se escudem na ausência dessas prerrogativas e poderes como principal razão da ineficácia e morosidade das investigações policiais, buscando, assim, fundamentar e justificar as "investigações ministeriais", não se vislumbra qualquer esforço desses mesmos críticos no sentido de conferir ao Delegado de Polícia essas merecidas garantias e poderes, muito pelo contrário. 
Nesse sentido, Luigi Ferrajoli já se manifestara pela necessidade de que a Polícia Judiciária não apenas seja organizada e separada rigidamente dos demais órgãos policiais, mas, que, sobretudo, disponha de garantias e prerrogativas necessárias ao exercício de suas funções institucionais, senão vejamos:

Na lógica do Estado de Direito, as funções de polícia deveriam ser limitadas a apenas três atividades: a atividade investigativa, com respeito aos crimes e aos ilícitos administrativos, a atividade de prevenção de uns ou de outros, e aquelas executivas e auxiliares da jurisdição e da administração. Nenhuma dessas atividades deveria comportar o exercício de poderes autônomos sobre as liberdades civis e sobre os outros direitos fundamentais. As diversas atribuiçôes, por fim, deveriam estar destinadas a corpos de policia separáveis entre eles entre eles e organizados de forma independente não apenas funcional, mas, também, hierarquicamente e administrativamente dos diversos poderes aos quais auxiliam. Em particular, a polícia judiciária, destinada, à investigação dos crimes e à execução dos provimentos jurisdicionais, deveria ser separa rigidamente dos outros corpos depolícia e dotada, em relação ao Executivo, das mesmas garantias de independência que são asseguradas ao Poder Judiciário ${ }^{45}$ do qual, deveria, exclusivamente, depender (FERRAJOLI, 2010, p. 709).

\section{Conclusões}

I. O sistema do inquérito policial, assim como previsto no ordenamento pátrio, se adeqúa ao sistema acusatório consagrado na $\mathrm{CF} / 88$. A uma, por respeitar e celebrar o princípio da igualdade das partes. A duas, pois, assegura que intervenção da Autoridade Judiciária durante as investigações se dê apenas para a apreciação de medidas judiciais necessárias à efetiva apuração dos fatos noticiados, quando direitos e garantias fundamentais estejam em jogo, ou ainda para coibir quaisquer abusos e ingerências no curso das mesmas. É, ainda, o sistema investigativo que se submete a mais mecanismos de controle (07), internos e externos, em todo o mundo. Revela-se, portanto, extremamente eficiente sob o ponto de vista das garantias do investigado e à concretização de uma investigação criminal em consonância com os ditames do Estado Democrático de Direito.

45 É interessante termos em mente que a Defensoria Pública da União e a Advocacia Geral da União, apesar de também inegavelmente pertencerem aos quadros do Poder Executivo Federal, já possuem autonomia expressamente previstas em nosso ordenamento pátrio. 
II. Das informações coligidas neste trabalho, verificou-se, ainda, que as taxas de elucidação de crimes, sobretudo homicídios, independem do modelo adotado, variando, bastante, até mesmo dentro de um mesmo país. Com efeito, em que pesem as críticas feitas ao inquérito policial, é interessante registrar que diversas delegacias de Polícia Civil, no Brasil têm obtido, nesses últimos anos, inegáveis avanços e excelentes resultados no combate a esse tipo de ilícito, superiores até aos índices obtidos historicamente em países ditos de $1^{\circ}$ mundo.

III. Em sentido contrário, sistemas que eventualmente são sugeridos pelos opositores do inquérito policial não demonstraram ser mais eficientes naqueles países que, nestes últimos anos, passaram a enfrentar graves problemas relacionados ao narcotráfico, à pobreza e ao crescimento e recrudescimento da violência urbana, como se pode verificar da queda (em alguns casos vertiginosa) nas taxas de elucidação enfrentadas no Uruguai (que adota o juizado de instrução), no México e em cidades norte-americanas como Chicago e Nova Iorque (que adotam, por seu turno, o sistema do promotor-investigador).

IV. Ainda nessa esteira de raciocínio, um estudo piloto na Superintendência da Polícia Federal em Roraima, realizado em 2014, demonstrou que, de todas as investigaçóes encerradas no ano de 2014 por aquela unidade, $70 \%$ (setenta por cento) o foram de forma exitosa, sendo que em $40 \%$ (quarenta por cento) houve indicação de autoria e em 30\% (trinta por cento) concluiu-se pela inexistência de crime.

V. Estudo preliminar, efetuado ao longo dos três primeiros meses de 2015, parece indicar que os índices da Polícia Federal como um todo não se distanciam em muito dos obtidos pela região de Roraima.

VI. Tudo isso, considerando que as taxas de elucidação dos crimes em geral na França, nos Estados Unidos e no Reino Unido, não superaram, via de regra, os $30 \%$, verifica-se que o inquérito policial realizado pela Polícia Federal, sob a presidência do delegado de polícia, permite resultados ainda superiores às polícias de outros países tidas como de $1^{\circ}$ mundo.

VII. Existem, obviamente, ainda, diversos obstáculos a uma maior eficiência da atividade investigativa através do inquérito policial, porém, os dados produzidos ao longo deste estudo demonstram que a Polícia Judiciária 
brasileira, com especial destaque à Polícia Federal, têm conseguido, inobstante as diversas críticas que se fazem ao modelo investigativo adotado, desenvolver um trabalho extremamente eficiente, sobretudo se considerarmos as limitações de toda a sorte a que os órgãos públicos, em especial as polícias, são submetidos (pessoal, material, financeiras etc.).

Franco Perazzoni

\begin{abstract}
Doutorando em Sustentabilidade Social e Desenvolvimento pela Universidade Aberta de Lisboa (Portugal). Mestre em

Ciência \& Sig pela Universidade Nova de Lisboa (Portugal). Especialista em Ciência Policial e Investigação Criminal pela Escola Superior de Polícia/MJ (2012). Especialista em Ciências Penais pela UNiSUl (2009). Especialista em Direito Ambiental pela PUCRS (2006). Graduado em Direito pela Fundação Universidade de Itaúna (2003). Graduado em Gestão Ambiental pela Universidade Católica Dom Bosco (2014).
\end{abstract}

E-MAIL: PERAZZONI.FP@DPF.GOV.BR

Wellington Clay Porcino Silva

Possui Mestrado em Ciências Militares pela Escola de Aperfeiçoamento de Oficiais do Exército. Atualmente

É Delegado - Departamento de Polícia Federal. Tem experiência na Área de Direito, com ênfase em Direito Penal, Análise Criminal e Inteligência.

E-MAIL:WELLINGTON.WCPS@DPF.GOV.BR

\title{
POLICE INQUIRY: AN EFFECTIVE AND INDISPENSABLE TOOL FOR INVESTIGATION
}

\section{ABSTRACT}

The resurgence of violence in recent years, led us to an intense distrust scenario in the Criminal Justice System, particularly in Public Security. For some, the true universal panacea of Brazilian Public Security problems would be so only the adoption of foreign models of police structure and therefore criminal investigation, as if the spread of crime was not caused by the numerous social changes over the last few decades, but rather the historic choice that Brazil has made regarding its criminal investigation model. Throughout this study, it will be sought to demonstrate that the results obtained by investigative police forces are much more dependent on the type of crime investigated and the society in which such corporation is inserted than the adopted research model. It will seen that in Brazil, despite the numerous criticisms, several judicial police units have achieved significant results, at levels even higher than the foreign police, considered reference. Moreover, we will see that, 
beyond qualitative aspect, the Brazilian police inquiry because of the impartial nature of the authority that presides, that is, the police chief, is the one best suited to a truly guarantee criminal proceedings, without neglecting necessary protection to society.

KEYWORDS: Systems of Criminal Investigation. Police investigation. Rate of Crime Resolution. Efficiency. Guaranteeism.

\title{
El Proceso de Averiguación Policial: una HERRAMIENTA EFICAZ Y ESENCIAL PARA LA INVESTIGACIÓN
}

\begin{abstract}
RESUMEN
El recrudecimiento de la violencia en los últimos años, nos ha llevado a un escenario de desconfianza intensa en el sistema de justicia penal, en particular en la Seguridad Pública. Para algunos, la verdadera panacea universal para los problemas de Seguridad Pública de Brasil serían tan sólo la adopción de modelos extranjeros de la estructura policial así como de la investigación criminal, como si la propagación del crimen no fuera causada por los numerosos cambios sociales en las últimas décadas, sino por la elección histórica que Brasil ha hecho con respecto a su modelo de investigación criminal. A lo largo de este estudio, se trató de demostrar que los resultados obtenidos por las fuerzas policiales de investigación son mucho más dependientes del tipo de delito investigado y la sociedad en que se inserta dicha corporación que del modelo de investigación adoptado. Se podrá comprobar, también, que en Brasil, a pesar de las numerosas críticas, varias unidades de la policía judicial han logrado resultados significativos, a niveles aún más altos de las policías extranjeras, consideradas de referencia. Por otra parte, vemos que además del aspecto cualitativo, el proceso de investigación policial de Brasil, debido a la naturaleza imparcial de la autoridad que preside, es decir, el comisario de la policía, es el que mejor se adapta a un proceso penal verdaderamente garantista, sin dejar de lado la protección necesaria a la sociedad.
\end{abstract}

Palabras Clave: Sistemas de Investigación Criminal. Investigación de la policía. Tasa de esclarecimiento de crímenes. Eficiencia. Garantismo. 


\section{REFERÊNCIAS}

CELESTINO, Samuel. Apenas 8,9\% das investigações do MPF são apresentadas à Justiça. Bahia Notícias. 17/04/2014. Disponível em: <http://www.bahianoticias.com.br/noticia/152064-apenas8-9-das-investigacoes-do-mpf-sao-apresentadas-a-justica.html> Acesso em: 12 jun. 2015.

COSTA, Arthur Trindade. A (in)efetividade da justiça criminal brasileira. Civitas, Porto Alegre, v. 15, n. 1, p. 11-26, jan.-mar. 2015

COSTA, Eduardo Maia. Que processo penal queremos? Congresso da Justiça. Disponível em <http://www.asficpj.org/temas/diversos/ congressojust/maia_costa.pdf >. Acesso em 10 mar. 2015.

DANTAS, George Felipe de Lima. Estudo sobre elucidação de homicídios apresenta contradições. Observatório da imprensa. Ed. 546. 14/07/2009. Disponível em: <http://observatoriodaimprensa. com.br/feitos-desfeitas/estudo-sobre-elucidacao-de-homicidiosapresenta-contradicoes>, Acesso em 10 jun. 2015.

DGPN. DIRECTION GENERALE DE LA POLICE NATIONALE. Crimes et delits constates en France en 2000 par les services de Police et de Gendarmerie. França, 2001.

EURES. European Employment Services. Rapporto Eures sugli Omicidi in Italia. Disponível em: <http://www.ristretti.it/areestudio/ statistiche/omicidi_2003.pdf>, Acesso em 12 jun. 2015.

FERRAJOLI, Luigi. Direito e Razão: teoria do garantismo penal. São Paulo: Ed. RT, 2002.

FOLHA. Sítio Eletrônico da Folha de São Paulo. De cada 10 homicídios na região de Ribeirão Preto 4 aguardam solução. Disponível em: <http://www1.folha.uol.com.br/cotidiano/ribeiraopreto/1236090de-cada-10-homicidios-na-regiao-de-ribeirao-preto-4-aguardamsolucao.shtml>, Acesso em 14 jun. 2015.

G1. Sítio Eletrônico do Portal G1. Polícia celebra alto índice de solução de homicídios em Araxá. Novembro/2014. Disponível em: <http://g1.globo.com/minas-gerais/triangulo-mineiro/ 
noticia/2014/11/policia-celebra-alto-indice-de-solucao-dehomicidios-em-araxa.html>, Acesso em 14 jun. 2015.

GOMES, Luiz Flávio. SCLIAR, Fábio. Crise do Inquérito Policial? Disponível em <http://www.lfg.com.br>. Acesso em 10 mar. 2015.

GOMES, Luiz Flávio. SCLIAR, Fábio. Delegado deveria ter mesmas prerrogativas de juiz. Disponível em < http://jusvi.com/ artigos/36799/2> Acesso em 15 mar. 2015.

GRANZOTTO, Claudio Geoffroy. Análise da investigação preliminar de acordo com seus possíveis titulares. Jus Navigandi. Disponível em: <http://jus.uol.com.br/revista/texto/9522>. Acesso em: 12 março. 2015.

HARGROVE, Thomas. Murder Mysteries. Scripps Howard News Service (SHNS). 2011.

ISACKSON, Noah. Chicago criminals are getting away with murder. Chicago Magazine. Maio/2013. Disponível em: <http://www. chicagomag.com/Chicago-Magazine/May-2013/Getting-Awaywith-Murder/>, Acesso em 02 jun. 2015.

LOPES JR, Aury. Sistemas de Investigação Preliminar no Processo

Penal. Rio de Janeiro: Lumen Juris, 2001, p. 97.

MACHADO, André Augusto Mendes. Investigação Criminal Defensiva. $1^{a}$ ed., São Paulo: Revista dos Tribunais, 2010.

MARTINEZ, Paris. 98\% de los homicidios de 2012 están impunes. Animal Político. 17/07/2013. Disponível em: <http://www. animalpolitico.com/2013/07/98-de-los-homicidios-de-2012-en-laimpunidad/>, Acesso em 10 jun. 2015.

MATO GROSSO. Sítio eletrônico do Governo de Mato Grosso. Delegacia de Homicídios mantém índices de mais de 80 de elucidação de crimes. Disponível em: <http://www.mt.gov.br/ editorias/geral/delegacia-de-homicidios-mantem-indices-de-maisde-80-de-elucidacao-de-crimes/46111 >, Acesso em 12 jun. 2015.

\section{MINISTÈRE DE JUSTICE. Statistiques: nombre d'homicides non} élucidés. Question n 30861 de M. Vanneste Christian (Union pour un Mouvement Populaire - Nord) QE. Ministère interrogé: 
Justice. Ministère attributaire: Justice. Question publiée au JO le: 16/09/2008 page: 7942. Réponse publiée au JO le 09/12/2008 page: 10720. Disponível em: <http://www.christianvanneste. fr/2008/12/04/statistiques-nombre-dhomocides-non-elucides-qe/> Acesso em: 12 jun. 2015.

MISSE, Michel; VARGAS, Joana. O fluxo do processo de incriminação no Rio de Janeiro na década de 50 e no período de 1997-2001: comparação e análise. $13^{\circ}$ Congresso Brasileiro de Sociologia, Recife, PE, 2007.

MURDERDATA. Disponível em: <http://murderdata.blogspot.com. br/>, Acesso em 02 jun. 2015.

PERFIL. Sítio eletrônico do jornal Perfil (Uruguai). Em Uruguay solo se resolven la mitad de los homicidios. 01/07/2015. Disponível em: $<$ http://www.perfil.com/policia/En-Uruguay-solo-se-resuelven-lamitad-de-los-homicidios-20150107-0051.html>, Acesso em 15 jun. 2015.

PITOMBO, Sérgio M. de Moraes. Inquérito Policial: Novas Tendências. - Belém: CEJUP, 1987.

PSNI. Police Service of Nothern Ireland. Statistics: Annual Statistical Report Statistical Report \# 1. Recorded crime \& Clearences. 01/04/2007 - 31/03/2008.

RATCLIFFE, J. H. INTELLIGENCE LED-POLICING. Routledge, NY, 2011.

RATTON, José Luis; CIRENO, Fernando. Violência endêmica: homicídios na cidade do Recife - dinâmica e fluxo no sistema de justiça criminal. Revista do Ministério Público de Pernambuco, v. 6, p. 17-157, 2007.

RIBEIRO, Ludmila. Administração da justiça criminal na cidade do Rio de Janeiro: uma análise dos casos de homicídios. Iuperj, Tese de Doutorado em Sociologia, 2009.

RIFIOTIS, Teophilos. Fluxo da justiça criminal em casos de homicídios dolosos na Região Metropolitana de Florianópolis entre os anos de 2000 e 2003. 2006. Mimeo.

REVISTA ACADEMICA - Estudos Avançados de Inquérito Policial - 
Academia de Ciências, Letras e Artes dos Delegados de Polícia do Estado de São Paulo. Ano I, 2.000, nº 03.

SAPORI, Luis Flávio. Segurança pública no Brasil: desafios e perspectivas. Rio de Janeiro: Ed. FGV, 2007.

SOARES, Luiz Eduardo. Violência e política no Rio de Janeiro. Rio de Janeiro: Relume-Dumará, 1996.

SSPDF. SECRETARIA DE SEGURANÇA PÚBLICA DO DISTRITO FEDERAL. Criminalidade no DF caiu pelo segundo ano consecutivo. Disponível em: <http://www.ssp.df.gov.br/sala-deimprensa/noticias/item/2670-criminalidade-no-df-diminuiu-pelosegundo-m\%C3\%AAs-consecutivo.html>, Acesso em 12 jun. 2015.

UCR-FBI. UNIFORM CRIME REPORTING - FEDERAL BUREAU OF INVESTIGATION. Disponível em: <http://www.ucrdatatool. gov/>, Acesso em 03 jun. 2015.

UBIRIA, RAFAEL (2005), El processo penal uruguayo actual: virtudes y defectos, Disponível em: http://www.serpaj.org.uy/serpajph/dcp/ seminarios/dcp_pon_ubiria.pdf, Acesso em 10 jun. 2015. 